\title{
Global Budget of Ethane and Regional Constraints on U.S. Sources
}

\section{Citation}

Xiao, Yaping, Jennifer A. Logan, Daniel J. Jacob, Rynda C. Hudman, Robert Yantosca, and Donald R. Blake. 2008. The global budget of ethane and regional constraints on U.S. sources. Journal of Geophysical Research 113(D21306): 1-13.

\section{Published Version}

doi:10.1029/2007JD009415

\section{Permanent link}

http://nrs.harvard.edu/urn-3:HUL.InstRepos:3554393

\section{Terms of Use}

This article was downloaded from Harvard University's DASH repository, and is made available under the terms and conditions applicable to Other Posted Material, as set forth at http:// nrs.harvard.edu/urn-3:HUL.InstRepos:dash.current.terms-of-use\#LAA

\section{Share Your Story}

The Harvard community has made this article openly available.

Please share how this access benefits you. Submit a story.

\section{Accessibility}




\title{
Global budget of ethane and regional constraints on U.S. sources
}

\author{
Yaping Xiao, ${ }^{1,2}$ Jennifer A. Logan, ${ }^{1}$ Daniel J. Jacob, ${ }^{1}$ Rynda C. Hudman, ${ }^{1}$ \\ Robert Yantosca, ${ }^{1}$ and Donald R. Blake ${ }^{3}$ \\ Received 24 September 2007; revised 19 August 2008; accepted 2 September 2008; published 5 November 2008.
}

[1] We use a 3-D chemical transport model (the GEOS-Chem CTM) to evaluate a global emission inventory for ethane $\left(\mathrm{C}_{2} \mathrm{H}_{6}\right)$, with a best estimate for the global source of $13 \mathrm{Tg} \mathrm{yr}^{-1}, 8.0 \mathrm{Tg} \mathrm{yr}^{-1}$ from fossil fuel production, $2.6 \mathrm{Tg} \mathrm{yr}^{-1}$ from biofuel, and $2.4 \mathrm{Tg} \mathrm{yr}^{-1}$ from biomass burning. About $80 \%$ of the source is emitted in the Northern Hemisphere. The model generally provides a reasonable and unbiased simulation of surface air observations, column measurements, and aircraft profiles worldwide, including patterns of geographical and seasonal variability. The main bias is a $20 \%-30 \%$ overestimate at European surface sites. Propagation of the $\mathrm{C}_{2} \mathrm{H}_{6}$ seasonal signal from northern midlatitudes to the equatorial western Pacific and the southern tropics demonstrates the dominance of northern midlatitudes as a source of $\mathrm{C}_{2} \mathrm{H}_{6}$ worldwide. Interhemispheric transport provides the largest $\mathrm{C}_{2} \mathrm{H}_{6}$ source to the Southern Hemisphere $\left(1.7 \mathrm{Tg} \mathrm{yr}^{-1}\right)$, and southern biomass burning provides the other major source $\left(1.0 \mathrm{Tg} \mathrm{yr}^{-1}\right)$. The $\mathrm{C}_{2} \mathrm{H}_{6}$ emission inventory for the United States from the Environmental Protection

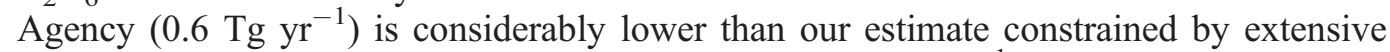
aircraft observations in the continental boundary layer $\left(2.4 \mathrm{Tg} \mathrm{yr}^{-1}\right)$. This appears to reflect a factor 7 underestimate in the fossil fuel source over the south-central United States. Our estimate of $\mathrm{C}_{2} \mathrm{H}_{6}$ emissions, together with observed ratios of $\mathrm{CH}_{4}: \mathrm{C}_{2} \mathrm{H}_{6}$, suggests that $\mathrm{CH}_{4}$ emissions from energy production in the U.S. may be underestimated by as much as $50 \%-100 \%$.

Citation: Xiao, Y., J. A. Logan, D. J. Jacob, R. C. Hudman, R. Yantosca, and D. R. Blake (2008), Global budget of ethane and regional constraints on U.S. sources, J. Geophys. Res., 113, D21306, doi:10.1029/2007JD009415.

\section{Introduction}

[2] Ethane $\left(\mathrm{C}_{2} \mathrm{H}_{6}\right)$ is the most abundant non-methane hydrocarbon in the atmosphere. It is an important source of peroxyacetylnitrate (PAN) which serves as a reservoir for nitrogen oxide radicals [Singh and Hanst, 1981; Kanakidou et al., 1991; Kasibhatla et al., 1993]. Its main sources are production, processing and transmission of fossil fuels, biofuel use, and biomass burning. It is the second most abundant constituent of natural gas after methane $\left(\mathrm{CH}_{4}\right)$. Ethane differs from most other hydrocarbons in that its fossil fuel source is primarily from various phases of natural gas production, transmission, and distribution, rather than from combustion. Atmospheric loss of $\mathrm{C}_{2} \mathrm{H}_{6}$ is by reaction with $\mathrm{OH}$, resulting in a mean atmospheric lifetime of $\sim 2$ months [Rudolph, 1995]. Strong correlations are often observed between $\mathrm{C}_{2} \mathrm{H}_{6}$ and $\mathrm{CH}_{4}$ in the atmosphere [Bartlett et al., 1996, 2003; Shipham et al., 1998], which could

\footnotetext{
${ }^{1}$ Department of Earth and Planetary Sciences and Division of Engineering and Applied Sciences, Harvard University, Cambridge, Massachusetts, USA.

${ }^{2}$ Now at Climate Change Research Center, University of New Hampshire, Durham, New Hampshire, USA.

${ }^{3}$ Department of Chemistry, University of California, Irvine, California, USA.

Copyright 2008 by the American Geophysical Union. 0148-0227/08/2007JD009415\$09.00
}

provide valuable constraints on the fuel source of $\mathrm{CH}_{4}$ and its contribution to radiative forcing of climate. Xiao et al. [2004] demonstrated that $\mathrm{C}_{2} \mathrm{H}_{6}-\mathrm{CH}_{4}-\mathrm{CO}$ correlations observed downwind of Asia, when interpreted quantitatively with a global chemical transport model, offer unique constraints on the magnitudes of $\mathrm{CH}_{4}$ sources from Asia and Europe. Simpson et al. [2006] used long-term measurements of $\mathrm{C}_{2} \mathrm{H}_{6}$ to show that recent fluctuations in the growth rate of $\mathrm{CH}_{4}$ are caused by interannual variability in biomass burning. General exploitation of $\mathrm{C}_{2} \mathrm{H}_{6}-\mathrm{CH}_{4}$ correlations requires a better understanding of the global sources of $\mathrm{C}_{2} \mathrm{H}_{6}$.

[3] Literature estimates for the global $\mathrm{C}_{2} \mathrm{H}_{6}$ source vary from 8 to $18 \mathrm{Tg} \mathrm{yr}^{-1}$ (Table 1). Most of these are simple topdown estimates in which an $\mathrm{OH}$ distribution was used to derive the source magnitude needed to match $\mathrm{C}_{2} \mathrm{H}_{6}$ observations. The EDGAR (Emission Database for Global Atmospheric Research) V2.0 inventory [Olivier et al., 1996] is at the bottom end of the range. It is based on activity rates and emission factors for total non-methane hydrocarbons, with $\mathrm{C}_{2} \mathrm{H}_{6}$ emissions derived from speciation profiles for various types of sources. Wang et al. [1998] used the bottom-up inventory of Piccot et al. [1992] for global emissions of alkanes from fossil fuel combustion and industrial activity, and assumed that $14 \%$ of these emissions were $\mathrm{C}_{2} \mathrm{H}_{6}$ (on a carbon basis) using speciation measured at a rural site in the eastern United States. However, since the higher alkanes are emitted primarily from fossil fuel combustion, while the 
Table 1. Literature Estimates of the Global $\mathrm{C}_{2} \mathrm{H}_{6}$ Source $\left(\mathrm{Tg} \mathrm{yr}^{-1}\right)$

\begin{tabular}{ll}
\hline \multicolumn{1}{c}{ Source } & \multicolumn{1}{c}{ Reference } \\
\hline 13 & Blake and Rowland $[1986]^{\mathrm{a}}$ \\
$15.0-16.3$ & Kanakidou et al. $[1991]$ \\
$10-15$ & Singh and Zimmerman $[1992]$ \\
$15.5(12.4)$ & Rudolph et al. $[1996]^{\mathrm{b}}$ \\
$16.3-17.6$ & Boissard et al. $[1996]$ \\
8.2 & EDGAR [Olivier et al., 1996$]^{\mathrm{c}}$ \\
10.4 & Gupta et al. $[1998]$ \\
10.8 & Wang et al. $[1998]^{\mathrm{d}}$ \\
18 & Thompson et al. $[2003]$ \\
13.5 & Xiao et al. $[2004]^{\mathrm{e}}$ \\
$\sim 12$ & Stein and Rudolph $[2007]^{\mathrm{f}}$ \\
13.0 & This work ${ }^{\mathrm{g}}$ \\
\hline
\end{tabular}

${ }^{\mathrm{a}}$ This is based on air samples collected in remote Pacific surface locations $\left(71^{\circ} \mathrm{N}-47^{\circ} \mathrm{S}\right)$.

${ }^{\mathrm{b}}$ Top-Down estimate is based on a global 2-D model and observed atmospheric concentrations, and bottom-up estimate in parentheses includes $6 \mathrm{Tg} \mathrm{yr}^{-1}$ from natural gas and $6.4 \mathrm{Tg} \mathrm{yr}^{-1}$ from biomass burning.

${ }^{c}$ Estimates are as follows: $3.2 \mathrm{Tg} \mathrm{yr}^{-1}$ from natural gas; $1.8 \mathrm{Tg} \mathrm{yr}^{-1}$ from biofuels; $1.2 \mathrm{Tg} \mathrm{yr}^{-1}$ from biomass burning; $1.3 \mathrm{Tg} \mathrm{yr}^{-1}$ from landfills, solvents, and waste treatment; and $0.7 \mathrm{Tg} \mathrm{yr}^{-1}$ from fossil fuel combustion.

${ }^{\mathrm{d}}$ Estimates are as follows: $7.8 \mathrm{Tg} \mathrm{yr}^{-1}$ from fossil fuel sector and $3 \mathrm{Tg} \mathrm{yr}^{-1}$ from biomass burning.

${ }^{\text {e}}$ Estimates are as follows: $8.0 \mathrm{Tg} \mathrm{yr}^{-1}$ from natural gas; $2.6 \mathrm{Tg} \mathrm{yr}^{-1}$ from biofuels, and $2.4 \mathrm{Tg} \mathrm{yr}^{-1}$ from biomass burning; this is the inventory used in the present work, with minor modifications given in the text.

${ }^{f}$ On the basis of EDGAR emission inventory, the 3-D model suggests that the overall underestimate of ethane sources in that inventory is in the range of $50 \%$.

${ }^{\mathrm{g}}$ As in Xiao et al. [2004] but with 30\% decrease in the European and 30\% increase in the Asian anthropogenic sources.

fossil fuel source of $\mathrm{C}_{2} \mathrm{H}_{6}$ is mainly from natural gas [Nelson et al., 1983; Rudolph, 1995], this simple scaling is probably not appropriate. We use here the source estimate of Xiao et al. [2004] which is described in more detail in section 2.

[4] The top-down estimates in Table 1 vary by almost a factor of 2 because of different data used for $\mathrm{C}_{2} \mathrm{H}_{6}$, different types of models (1-, 2- and 3-dimensional) and assumed $\mathrm{OH}$ distributions, and different assumptions about the spatial patterns of emissions. Blake and Rowland [1986] and Gupta et al. [1998] used observations from remote surface locations along the Pacific Rim, while Boissard et al. [1996] used aircraft data from flights around the Atlantic Ocean. Rudolph [1995] used a more comprehensive data set including shipboard and aircraft observations from the remote troposphere in 1980-1992. Their top-down estimate is consistent with their independent bottom-up estimate. Thompson et al. [2003] and Stein and Rudolph [2007] relied on the same data as Rudolph and the OH fields from Spivakovsky et al. [2000]; they used the EDGAR inventory and found that they needed to scale the sources by a factor of $1.5-2.2$ to match observed $\mathrm{C}_{2} \mathrm{H}_{6}$.

[5] Emission estimates for the United States compiled by the Environmental Protection Agency (EPA) appear to be 2-3 times too low relative to top-down constraints. This was first pointed out by Wang et al. [1998] for the 1985 NAPAP inventory which gave an estimate of $0.43 \mathrm{Tg} \mathrm{yr}^{-1}$ for the U.S. source of $\mathrm{C}_{2} \mathrm{H}_{6}$, and we find that the discrepancy persists in the EPA National Emission Inventory for 1999 (NEI-99) which gives an estimate of $0.6 \mathrm{Tg} \mathrm{yr}^{-1}$. Katzenstein et al. [2003] used their surface observations of
$\mathrm{C}_{2} \mathrm{H}_{6}$ to infer a source of $0.3-0.5 \mathrm{Tg} \mathrm{yr}^{-1}$ in the southcentral United States where much of the natural gas industry is located; the EPA inventory gives a source of only $0.15 \mathrm{Tg} \mathrm{yr}^{-1}$ for the same region. The Energy Information Administration (EIA) national inventory for $\mathrm{CH}_{4}$ gives an estimate for emissions from fossil fuels of $10.5 \mathrm{Tg} \mathrm{yr}^{-1}$ in the U.S. for 2005 [EIA, 2007]. The top-down analysis of the global $\mathrm{CH}_{4}$ budget of Wang et al. [2004] implies that emissions of $\mathrm{CH}_{4}$ in the U.S. are $20 \mathrm{Tg} \mathrm{yr}^{-1}$ for 1998 (J. Wang, personal communication, 2004).

[6] We present here a comprehensive evaluation of the global $\mathrm{C}_{2} \mathrm{H}_{6}$ budget by testing a bottom-up emission inventory with surface and aircraft observations, as well as ground-based column measurements. We also present a focused analysis of U.S. sources by using an extensive data set of aircraft observations for the U.S. boundary layer from the NASA INTEX-A campaign in July-August 2004 [Singh et al., 2006].

\section{Model Description}

\subsection{General Description}

[7] We use the GEOS-Chem chemical transport model (CTM) version 6.01.03 (http://www.as.harvard.edu/chemistry/ trop/geos/index.html), driven by assimilated meteorological fields from the Goddard Earth Observing System (GEOS) of the NASA Global Modeling and Assimilation Office (GMAO). A general description of the model is given by Bey et al. [2001]. Most of our analysis is based on a simulation for 2001 (after 6 months of initialization). The INTEX-A observations are interpreted with a simulation for July-August 2004 (after two months of initialization). The GEOS meteorological fields have $1^{\circ} \times 1^{\circ}$ horizontal resolution and 48 vertical layers (GEOS-3, used for 2001), and $1^{\circ} \times$ $1.25^{\circ}$ resolution and 55 layers (GEOS-4, used for 2004), with 6 hour temporal resolution (3-hour for mixing depths and surface properties). For computational expediency, we degrade the horizontal resolution in GEOS-Chem to $2^{\circ}$ latitude $\times 2.5^{\circ}$ longitude.

[8] Our simulation tracks separately the $\mathrm{C}_{2} \mathrm{H}_{6}$ originating from different regions in order to facilitate source attribution. The sources of $\mathrm{C}_{2} \mathrm{H}_{6}$ are discussed below. Loss of $\mathrm{C}_{2} \mathrm{H}_{6}$ is exclusively by reaction with $\mathrm{OH}$, with a rate constant of $8.7 \times 10^{-12} \exp (-1070 / \mathrm{T}) \mathrm{cm}^{3}$ molecule $\mathrm{s}^{-1} \mathrm{~s}^{-1}$ from Sander et al. [2003]. Ethane is removed primarily by reaction with $\mathrm{Cl}$ atoms in the stratosphere, but this process provides only $2 \%$ of the global sink [Gupta et al., 1998]. Reaction with Cl may play a significant role in some environments, such as the arctic and the marine boundary layer [Jobson et al., 1994; Singh et al., 1996]. We do not include reaction of $\mathrm{C}_{2} \mathrm{H}_{6}$ with $\mathrm{Cl}$ because of its small role in the global budget. We use archived monthly mean 3-D $\mathrm{OH}$ concentrations from a GEOS-Chem simulation of tropospheric chemistry [Fiore et al., 2003]. These concentrations yield an annual mean lifetime of methylchloroform with respect to loss by tropospheric $\mathrm{OH}$ of 6.3 years, as compared with the range of 5.6-6.5 years given by Prinn et al. [2005] and 5.7 years given by Spivakovsky et al. [2000], based on methyl chloroform measurements. The resulting mean tropospheric lifetime of $\mathrm{C}_{2} \mathrm{H}_{6}$ in the model is 80 days on a global basis, 49 days in the tropics, and 57 days in the extratropics in summer and 10 months in winter. We also include $\mathrm{C}_{2} \mathrm{H}_{6}$ loss 
Table 2. $\mathrm{C}_{2} \mathrm{H}_{6}$ Source Types and Regions Used in the Model $\left(\operatorname{Tg~}^{-1}\right)$

\begin{tabular}{lccc}
\hline & Fossil Fuel & Biofuel & $\begin{array}{c}\text { Biomass } \\
\text { Burning }\end{array}$ \\
\hline Global & 8.0 & 2.6 & 2.4 \\
Northern Hemisphere & 7.4 & 2.1 & 1.4 \\
$\quad$ Asia $\left(0-88^{\circ} \mathrm{N}, 65-153^{\circ} \mathrm{E}\right)$ & 2.0 & 1.6 & 0.8 \\
$\quad$ Europe $\left(35-75^{\circ} \mathrm{N}\right.$, & 1.9 & 0.2 & $<0.1$ \\
$\left.\quad 18^{\circ} \mathrm{W}-65^{\circ} \mathrm{E}\right)$ & & & \\
$\quad$ North America & $2.4^{\mathrm{b}}$ & $<0.1$ & $<0.1^{\mathrm{c}}$ \\
$\quad\left(24-80^{\circ} \mathrm{N}, 125-65^{\circ} \mathrm{W}\right)^{\mathrm{a}}$ & & & \\
$\quad$ Other & 1.1 & 0.2 & 0.5 \\
Southern Hemisphere & 0.6 & 0.5 & 1.0 \\
\hline
\end{tabular}

aNote that the "North America" defined here is different from the United States, with the latter covering the geographical region of $25-50^{\circ} \mathrm{N}$ and $125-65^{\circ} \mathrm{W}$.

${ }^{\mathrm{b}}$ Optimized sources are based on the INTEX-A observations (section 5).

${ }^{\mathrm{c}}$ The daily biomass burning emission inventory for Alaska and NW Canada gives emissions of $0.030 \mathrm{Tg}$ in July and August for 2004, as compared to $0.014 \mathrm{Tg}$ in July and August in the climatology.

in the stratosphere using zonal mean $\mathrm{OH}$ concentrations from Schneider et al. [2000].

\subsection{Ethane Emissions}

[9] The $\mathrm{C}_{2} \mathrm{H}_{6}$ sources used in the model are from Xiao et al. [2004] with modifications described below. In our earlier work, sources of $\mathrm{C}_{2} \mathrm{H}_{6}$ were derived by scaling emissions of $\mathrm{CH}_{4}$, because the two gases have sources in common from fossil fuel production, biofuel combustion, and biomass burning. We scaled $\mathrm{CH}_{4}$ sources inferred for 1998 by Wang et al. [2004] from an inverse model analysis of $\mathrm{CH}_{4}$ surface observations. Wang et al. relied on the geographical distributions of Fung et al. [1991], along with temporal scaling, for their prior sources of $\mathrm{CH}_{4}$. Xiao et al. [2004] derived $\mathrm{C}_{2} \mathrm{H}_{6}$ emissions from the sum of $\mathrm{CH}_{4}$ emissions from natural gas and oil leakage, natural gas venting, and coal mining (without attempting to differentiate among these sources), with the following molar emission ratios for $\mathrm{CH}_{4} / \mathrm{C}_{2} \mathrm{H}_{6}: 8$ for eastern Russia, 24 for Europe, 40 for East Asia, and 19 for the rest of the world (ROW), including North America. The ratio of 40 for East Asia resulted from using the inventory of Streets et al. [2003] for $\mathrm{C}_{2} \mathrm{H}_{6}$. The ratios in other regions were adopted to give a reasonable simulation of $\mathrm{C}_{2} \mathrm{H}_{6}$ observations, but we did not evaluate the global model in detail.

[10] In this work we conducted an extensive evaluation of the $\mathrm{C}_{2} \mathrm{H}_{6}$ simulation with observations (section 4). On the basis of the analysis shown below, we reduced the European $\mathrm{C}_{2} \mathrm{H}_{6}$ emissions in the study of Xiao et al. [2004] by $30 \%$ and increased Asian emissions by $30 \%$ to better match the observations. (Note that all the results shown below are with these modifications.) These changes imply $\mathrm{CH}_{4} / \mathrm{C}_{2} \mathrm{H}_{6}$ molar emission ratios of 34 for Europe and 31 for Asia. We distributed the $\mathrm{C}_{2} \mathrm{H}_{6}$ emissions over the United States following spatial distribution in the EPA NEI-99 inventory but retained the national total of Xiao et al., 2.2 $\mathrm{Tg} \mathrm{yr}^{-1}$ which is a factor of 3.5 higher than the EPA estimate of $0.6 \mathrm{Tg} \mathrm{yr}^{-1}$.

[11] The ratios used for $\mathrm{CH}_{4} / \mathrm{C}_{2} \mathrm{H}_{6}$ in different continents are reasonable given measurements of this ratio in natural gas. For example, the ratio is $\sim 32$ for natural gas/ oil distribution networks in the United Kingdom [U.K. Photochemical Oxidants Review Group, 1997], and $\sim 23$ for natural gas use in Korea [Na et al., 2004]. Atmospheric measurements of $\mathrm{CH}_{4}$ and $\mathrm{C}_{2} \mathrm{H}_{6}$ near source regions give a ratio of 19 for $\mathrm{CH}_{4} / \mathrm{C}_{2} \mathrm{H}_{6}$ in samples collected downwind of natural gas plants in the southern United States and 7 in a sample downwind of an oil storage tank [Katzenstein et al., 2003], and 5-35 in Chinese cities where natural gas, oil, and coal are expected to be the dominant fossil fuel sources [Barletta et al., 2005].

[12] The ratio of $\mathrm{CH}_{4} / \mathrm{C}_{2} \mathrm{H}_{6}$ in natural gas varies with the type of gas or oil field; ratios are highest for "dry" gas fields (20-100), intermediate for gas condensate fields $(10-20)$ and lowest for oil fields $(4-10)$ according to the review by Jones et al. [1999]. Dry gas fields are those that lack condensate or liquid hydrocarbons, and the natural gas is almost pure $\mathrm{CH}_{4}$. In gas condensate fields, a low-density liquid hydrocarbon phase occurs along with the natural gas, and its presence as a liquid phase depends on temperature and pressure conditions in the reservoir. Ratios for $\mathrm{CH}_{4} /$ $\mathrm{C}_{2} \mathrm{H}_{6}$ in coal mines gas are much higher if the $\mathrm{CH}_{4}$ is biogenic origin $(>200$ to $>10,000)$, rather than of thermogenic origin $(\sim 10)$, as shown for example by Strapoć et al. [2007] for coalbed gas from mines in Indiana and Kentucky respectively. Coalbed methane is often a mix of biogenic and thermogenic $\mathrm{CH}_{4}$. Use of these ratios in a bottom-up estimate of $\mathrm{C}_{2} \mathrm{H}_{6}$ would require detailed information on $\mathrm{CH}_{4}$ emissions and on $\mathrm{CH}_{4} / \mathrm{C}_{2} \mathrm{H}_{6}$ ratios from specific gas, oil, and coal fields, and is beyond the scope of the present work.

[13] The source of $\mathrm{C}_{2} \mathrm{H}_{6}$ from biomass burning is scaled to the gridded climatological biomass burning inventory for CO from Duncan et al. [2003] with monthly resolution. The annual source of $\mathrm{CO}$ from biomass burning is $410 \mathrm{Tg}$ [Duncan et al., 2007]. The $\mathrm{C}_{2} \mathrm{H}_{6} / \mathrm{CO}$ emission ratios applied to the CO inventory [Staudt et al., 2003] depend on fuel type and are (in $10^{-3} \mathrm{~mol} \mathrm{~mol}^{-1}$ ) 4.7 for tropical deforestation, 5.8 for extratropical forest fires, 4.6 for savanna/ grassland, 6.8 for shrub fires, and 9.8 for agriculture residue, taken from the review of Andreae and Merlet [2001]. The resulting global biomass burning source of $\mathrm{C}_{2} \mathrm{H}_{6}$ is $2.4 \mathrm{Tg} \mathrm{yr}^{-1}$, with $40 \%$ in the Southern Hemisphere. For the INTEX-A simulation, we superimpose a daily biomass burning emission inventory for Alaska and NW Canada for the summer of 2004, with injection of $60 \%$ of emissions above the boundary layer [Turquety et al., 2007]. The fires were a major perturbation to $\mathrm{CO}$ over North America that summer [Pfister et al., 2005; Turquety et al., 2007] but the effect on $\mathrm{C}_{2} \mathrm{H}_{6}$ is modest on the continental scale, amounting to $15 \%$ of the fossil fuel source for the July-August period.

[14] The biofuel source is derived from the gridded aseasonal CO emission inventory of Yevich and Logan [2003] with an emission ratio of $14 \times 10^{-3} \mathrm{~mol} \mathrm{~mol}^{-1}$ for $\mathrm{C}_{2} \mathrm{H}_{6} / \mathrm{CO}$ [Bertschi et al., 2003], except for Asia where we superimpose the biofuel source of $\mathrm{C}_{2} \mathrm{H}_{6}$ from Streets et al. [2003]. The latter inventory has a similar magnitude to that of Yevich and Logan but a different spatial distribution. The $\mathrm{C}_{2} \mathrm{H}_{6} / \mathrm{CO}$ emission ratio is considerably higher than for biomass burning, possibly due to flaming combustion 


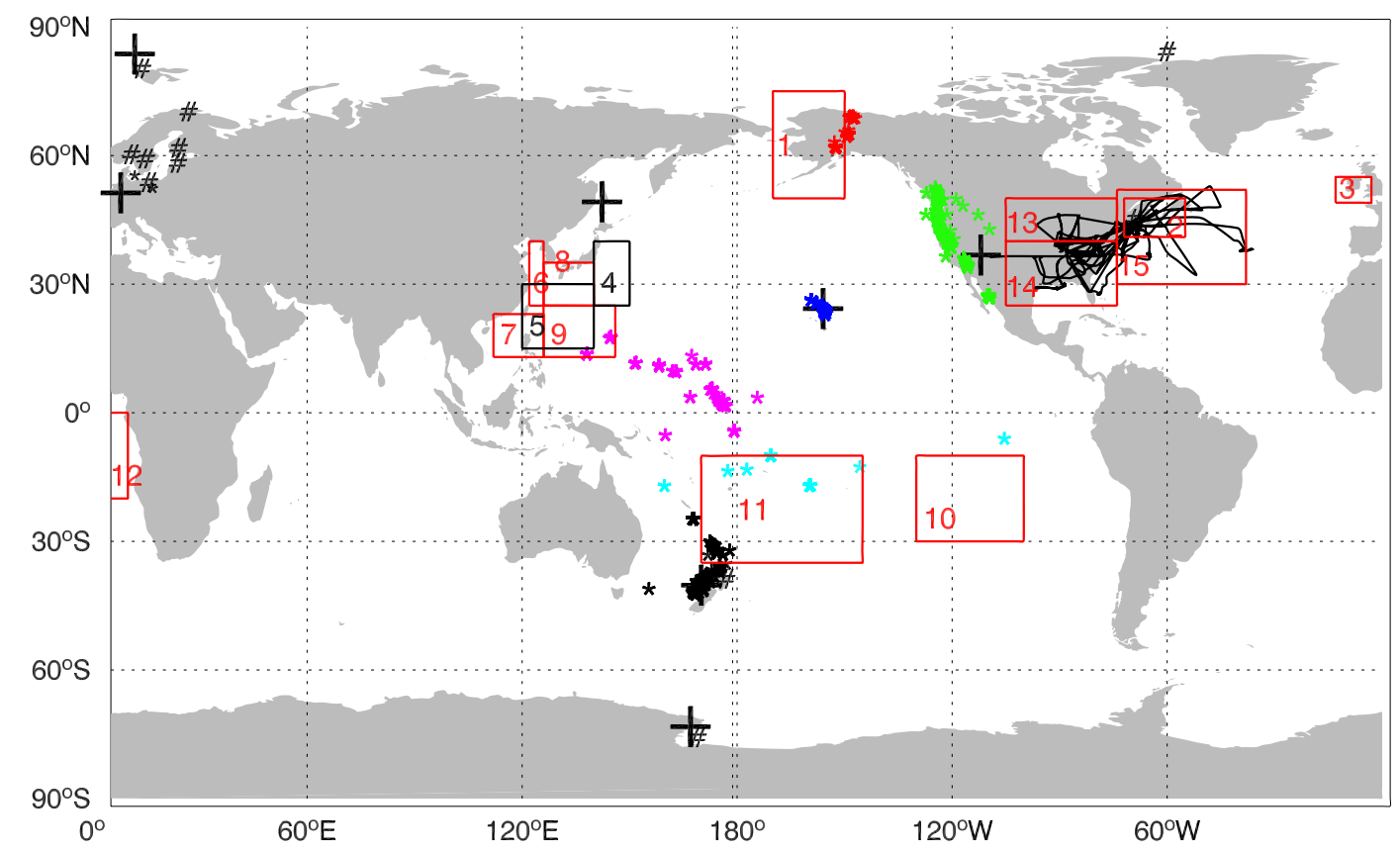

Figure 1. Locations of $\mathrm{C}_{2} \mathrm{H}_{6}$ observations used in our analysis: surface sites with year-round data (number sign); surface data from Blake [2005] (asterisk) for Alaska (red), western U.S. (green), Hawaii (blue), equatorial western Pacific (magenta), southern tropical Pacific (cyan), and southern extratropics (black); ground-based column sites (plus); and aircraft missions (red boxes) with region numbers indicated. Flight tracks for INTEX-A are shown. Further details are given in Table 3.

[Bertschi et al., 2003]. The global biofuel source of $\mathrm{C}_{2} \mathrm{H}_{6}$ is $2.6 \mathrm{Tg} \mathrm{yr}^{-1}$, with $70 \%$ from Asia and most of the rest from Africa.

[15] Biogenic and ocean sources of $\mathrm{C}_{2} \mathrm{H}_{6}$ are negligibly small, and were not considered in this work [Plass-Dülmer et al., 1995; Rudolph, 1995].

[16] Table 2 gives the global emission of $\mathrm{C}_{2} \mathrm{H}_{6}$ used in our study and the contributions from different source types and continents. The global source is $13.0 \mathrm{Tg} \mathrm{yr}^{-1}$ including $62 \%$ from fossil fuel, $20 \%$ from biofuel, and $18 \%$ from biomass burning; $84 \%$ of the source is in the Northern Hemisphere. The fuel sources in Asia (3.6 $\mathrm{Tg} \mathrm{yr}^{-1}$ ), Europe (2.1 $\mathrm{Tg} \mathrm{yr}^{-1}$ ) and North America (2.4 $\mathrm{Tg} \mathrm{yr}^{-1}$ ) are of similar magnitude and represent the major regions of emissions.

\section{Observations Used for Model Evaluation}

[17] Figure 1 shows the locations of $\mathrm{C}_{2} \mathrm{H}_{6}$ measurements from surface stations (in situ and column) and aircraft missions used to evaluate model results. Details are given in Table 3. Measurements from the surface stations in Table 3 have year-round data and are grouped regionally for model evaluation. To expand coverage in the remote troposphere (particularly in the tropics), we include also the network of surface Pacific sites maintained by the University of California at Irvine [Blake, 2005], referred to below as the UCI data. These data are from flask samples taken 4 times a year between 1996 and 2003. We group them into 6 geographic regions (Figure 1) and exclude samples outside the median $\pm 2 \sigma$ range to avoid local contamination. The column observations are from multiyear tropospheric records, omitting data from September 1997 to September 1998 because of the unusual fire influence [Rinsland et al., 1999].

[18] Monthly mean model results for 2001 are sampled at the individual stations and over the aircraft flight regions (Figure 1). The model results are compared to the observed multi-year monthly means at the stations and to the observed regional vertical profiles for the aircraft missions. Station data show that interannual variability in $\mathrm{C}_{2} \mathrm{H}_{6}$ is relatively small. Temporal mismatches for the model-data comparison may introduce uncertainty in the model evaluation, but the use of averages over several years reduces this problem for the station data. The meteorology in 2001 can be considered as typical because of lack of the large-scale anomalies in transport patterns. Differences in meteorology are most likely to influence the aircraft comparisons, as the data are often from only a few days. This is the case for results for SONEX (1997) and PEM Tropics A (1996) as discussed in section 4.2. Longterm decreases in $\mathrm{C}_{2} \mathrm{H}_{6}$ columns have been reported for Kitt Peak, Arizona, for 1977-1997 (-1.20 $\pm 0.35 \% \mathrm{yr}^{-1}$; Rinsland et al. [1998]) and for Jungfraujoch, Switzerland, for 1985-1995 (-2.7 $\pm 0.3 \% \mathrm{yr}^{-1} ;$ Mahieu et al. [1997]). Most of the observations that we use in this work (Table 3) are from the 1990s, and large trends are not evident during this period.

[19] The other possible sources of uncertainties for model evaluation include model $\mathrm{OH}$ concentrations, the reaction rate of $\mathrm{C}_{2} \mathrm{H}_{6}$ with $\mathrm{OH}$, intrinsic model transport errors, and errors in prescribed emission distribution. Our model repro- 
Table 3. Atmospheric $\mathrm{C}_{2} \mathrm{H}_{6}$ Measurements

\begin{tabular}{|c|c|c|}
\hline Location & Period & Reference \\
\hline \multicolumn{3}{|l|}{ Surface stations $\mathrm{s}^{\mathrm{a}}$} \\
\hline \multicolumn{3}{|l|}{ Arctic } \\
\hline Alert $\left(82^{\circ} \mathrm{N}, 63^{\circ} \mathrm{W}\right)$ & $1989-1996$ & Gautrois et al. [2003] \\
\hline Zeppelin $\left(78^{\circ} \mathrm{N}, 11^{\circ} \mathrm{E}\right)$ & 1989-1994 & Solberg et al. [1996] \\
\hline \multicolumn{3}{|l|}{ Northern Europe } \\
\hline Pallas $\left(68^{\circ} \mathrm{N}, 24^{\circ} \mathrm{E}\right)$ & $1994-1994$ & Laurila and Hakola [1996] \\
\hline Uto $\left(60^{\circ} \mathrm{N}, 21^{\circ} \mathrm{E}\right)$ & $1993-1994$ & Laurila and Hakola [1996] \\
\hline Birkenes $\left(58^{\circ} \mathrm{N}, 8^{\circ} \mathrm{E}\right)$ & $1988-1994$ & Solberg et al. [1996] \\
\hline Rorvik $\left(57^{\circ} \mathrm{N}, 12^{\circ} \mathrm{E}\right)$ & $1989-1990$ & Lindskog and Moldanova [1994] \\
\hline \multicolumn{3}{|l|}{ Central Europe } \\
\hline Waldhof $\left(52^{\circ} \mathrm{N}, 10^{\circ} \mathrm{E}\right)$ & $1992-1994$ & Solberg et al. [1996] \\
\hline Melpitz $\left(52^{\circ} \mathrm{N}, 13^{\circ} \mathrm{E}\right)$ & $1993-1994$ & Gnauk and Rolle [1998] \\
\hline Kosetice $\left(49^{\circ} \mathrm{N}, 15^{\circ} \mathrm{E}\right)$ & $1992-1994$ & Solberg et al. [1996] \\
\hline Harvard Forest $\left(43^{\circ} \mathrm{N}, 72^{\circ} \mathrm{W}\right)$ & $1992-1994$ & Goldstein et al. [1995] \\
\hline \multicolumn{3}{|l|}{ Extratropical Southern Hemisphere } \\
\hline Baring Head $\left(41^{\circ} \mathrm{S}, 174^{\circ} \mathrm{E}\right)$ & $1991-1996$ & Clarkson et al. [1997] \\
\hline Scott Base $\left(78^{\circ} \mathrm{S}, 166^{\circ} \mathrm{E}\right)$ & $1991-1996$ & Clarkson et al. [1997] \\
\hline \multicolumn{3}{|l|}{ Ground-based column stations } \\
\hline Spitsbergen $\left(79^{\circ} \mathrm{N}, 12^{\circ} \mathrm{E}\right)$ & 1992-1999 & Notholt et al. [1997] \\
\hline Jungfraujoch $\left(47^{\circ} \mathrm{N}, 8^{\circ} \mathrm{E}, 3.6 \mathrm{~km}\right)$ & $1985-1999$ & Mahieu et al. [1997] \\
\hline Japan $\left(44^{\circ} \mathrm{N}, 143^{\circ} \mathrm{E}\right)^{\mathrm{b}}$ & $1995-2000$ & Zhao et al. [2002] \\
\hline Kitt Peak $\left(32^{\circ} \mathrm{N}, 112^{\circ} \mathrm{W}, 2.1 \mathrm{~km}\right)$ & $1982-1997$ & Rinsland et al. [1998] \\
\hline Mauna Loa $\left(20^{\circ} \mathrm{N}, 156^{\circ} \mathrm{W}, 3.5 \mathrm{~km}\right)$ & $1995-1998$ & Rinsland et al. [1999] \\
\hline Lauder $\left(45^{\circ} \mathrm{S}, 170^{\circ} \mathrm{E}, 0.4 \mathrm{~km}\right)$ & $1997-2003$ & Rinsland et al. $[1998,2002]$ \\
\hline \multicolumn{3}{|l|}{ Aircraft missions } \\
\hline 1: ABLE-3A, Alaska $\left(50-75^{\circ} \mathrm{N}, 150-170^{\circ} \mathrm{E}\right)$ & Jul-Aug 1988 & Harriss et al. [1992] \\
\hline 2: SONEX, Maine $\left(41-50^{\circ} \mathrm{N}, 55-72^{\circ} \mathrm{W}\right)$ & Oct-Nov 1997 & Thompson et al. [2000] \\
\hline \multicolumn{3}{|l|}{ 3: SONEX, Ireland $\left(49-54^{\circ} \mathrm{N}, 3-13^{\circ} \mathrm{W}\right)$} \\
\hline 4: PEM-West A, south Japan coast $\left(25-40^{\circ} \mathrm{N}, 140-150^{\circ} \mathrm{E}\right)$ & Sep-Oct 1991 & Hoell et al. [1996] \\
\hline 5: PEM-West A, southeast China coast $\left(15-30^{\circ} \mathrm{N}, 120-140^{\circ} \mathrm{E}\right)$ & Sep-Oct 1991 & Hoell et al. [1996] \\
\hline 6: TRACE-P, China coast $\left(25-40^{\circ} \mathrm{N}, 122-126^{\circ} \mathrm{E}\right)$ & Feb-Apr 2001 & Jacob et al. [2003] \\
\hline \multicolumn{3}{|l|}{ 7: TRACE-P, south China coast $\left(13-23^{\circ} \mathrm{N}, 112-126^{\circ} \mathrm{E}\right)$} \\
\hline \multicolumn{3}{|l|}{ 8: TRACE-P, south Japan coast $\left(25-35^{\circ} \mathrm{N}, 126-140^{\circ} \mathrm{E}\right)$} \\
\hline \multicolumn{3}{|l|}{ 9: TRACE-P, west tropical Pacific $\left(13-25^{\circ} \mathrm{N}, 126-146^{\circ} \mathrm{E}\right)$} \\
\hline 10: PEM-Tropics B, southern tropical Pacific $\left(10-30^{\circ} \mathrm{S}, 100-130^{\circ} \mathrm{W}\right)$ & Mar-Apr 1999 & Raper et al. [2001] \\
\hline 11: PEM-Tropics A, southern tropical Pacific $\left(10-35^{\circ} \mathrm{S}, 170-215^{\circ} \mathrm{E}\right)$ & Aug-Sep 1996 & Hoell et al. [1999] \\
\hline 12: TRACE-A, African west coast $\left(0-20^{\circ} \mathrm{S}, 0-10^{\circ} \mathrm{E}\right)$ & Sep-Oct 1992 & Blake et al. [1996] \\
\hline 13: INTEX-A, northern North America $\left(40-55^{\circ} \mathrm{N}, 105-76^{\circ} \mathrm{W}\right)$ & Jul-Aug 2004 & Singh et al. [2006] \\
\hline 14: INTEX-A, southern North America $\left(25-40^{\circ} \mathrm{N}, 105-76^{\circ} \mathrm{W}\right)$ & & \\
\hline 15: INTEX-A, offshore North America $\left(30-55^{\circ} \mathrm{N}, 76-35^{\circ} \mathrm{W}\right)$ & & \\
\hline
\end{tabular}

${ }^{a}$ These are stations with continuous measurements for at least a year. We also use the University of California at Irvine (UCI) Pacific data network of Blake [2005], including 4 flask samples per year for 1996-2003, to expand geographical coverage, particularly in the tropics. See Figure 1 and text for details.

${ }^{\mathrm{b}}$ Placed are as follows: Moshiri $\left(44^{\circ} \mathrm{N}, 142^{\circ} \mathrm{E}\right)$ and Rikubetsu $\left(44^{\circ} \mathrm{N}, 144^{\circ} \mathrm{E}\right)$.

duces the seasonal variation of $\mathrm{C}_{2} \mathrm{H}_{2}$ [Xiao et al., 2007], a species with shorter lifetime than that of $\mathrm{C}_{2} \mathrm{H}_{6}$, validating the seasonal variation of $\mathrm{OH}$ in the model [Goldstein et al., 1995]. The uncertainty in the rate constant for $\mathrm{OH}$ with
$\mathrm{C}_{2} \mathrm{H}_{6}$ is only $15 \%$ [Atkinson, 2000]. Uncertainty in model transport or in emission distributions are difficult to quantify. As shown below, the good agreement between modeled and observed $\mathrm{C}_{2} \mathrm{H}_{6}$ indicates that the model realistically

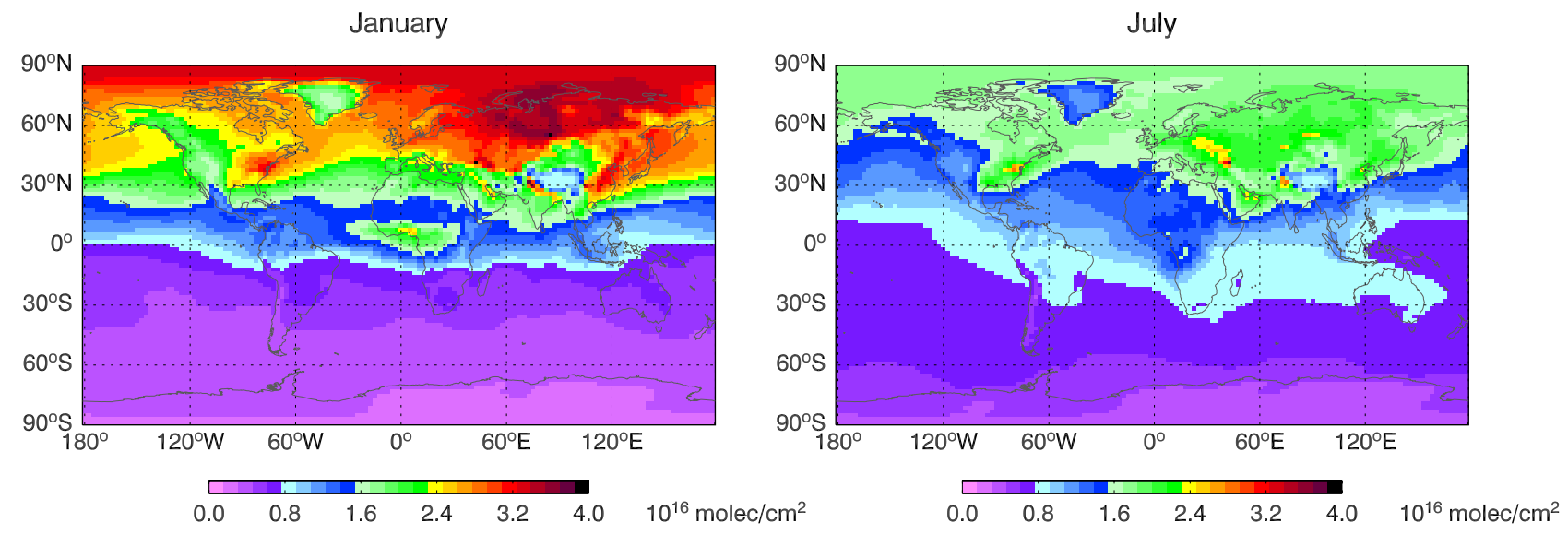

Figure 2. Simulated monthly mean atmospheric $\mathrm{C}_{2} \mathrm{H}_{6}$ columns $\left(10^{16}\right.$ molecules $\left./ \mathrm{cm}^{2}\right)$ in January and July. 


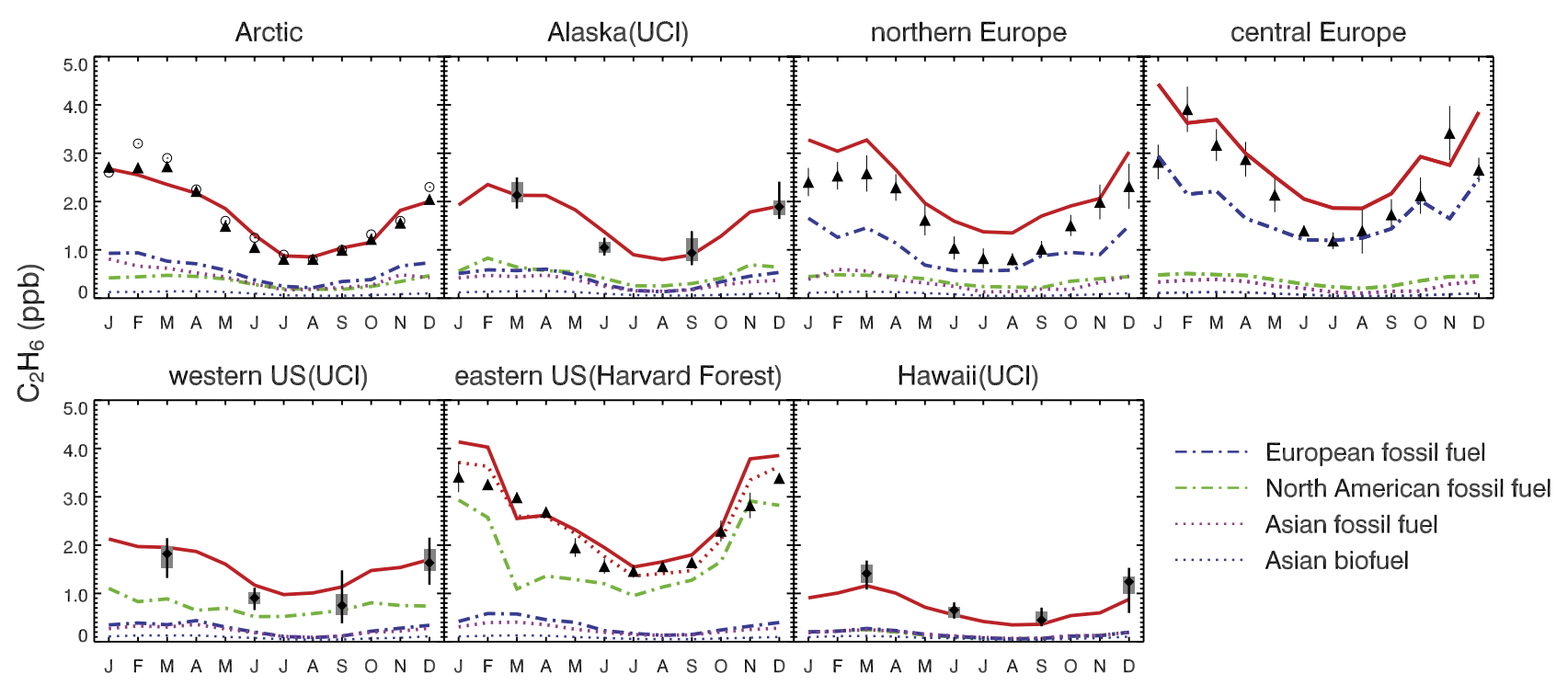

Figure 3a. Surface air $\mathrm{C}_{2} \mathrm{H}_{6}$ mixing ratios for the sites in Figure 1. Model values (red lines) are compared to observations (black). For UCI data, the diamonds are monthly medians, with points outside the median $\pm 2 \sigma$ excluded; the 25 th and 75 th percentiles (boxes) and 10th and 90th percentiles (vertical bars) are also shown. Arctic data are from Alert (open circle) and Zeppelin (solid triangle). Observations for other regions are monthly means (black triangle) \pm 1 standard deviation. Model results with optimized North American sources on the basis of the INTEX-A aircraft data (section 5) are shown for Harvard Forest (red dotted) and not for other sites where differences with the standard simulation are negligible. Also shown as dashed and dotted lines are contributions from major source types and regions to the model $\mathrm{C}_{2} \mathrm{H}_{6}$.

describes the most important transport processes and the major characteristics of $\mathrm{C}_{2} \mathrm{H}_{6}$ emissions.

\section{Model Evaluation}

[20] Figure 2 shows the simulated monthly mean atmospheric $\mathrm{C}_{2} \mathrm{H}_{6}$ columns in January and July. There are strong latitudinal and seasonal variations reflecting the distribution of the sources and the photochemical sink. The tropospheric lifetime of $\mathrm{C}_{2} \mathrm{H}_{6}$ is sufficiently long to allow $\mathrm{C}_{2} \mathrm{H}_{6}$ to mix zonally but sufficiently short to yield strong latitudinal and seasonal variations. Maximum concentrations over the Arctic in winter reflect the transport of pollution from northern midlatitudes and the long lifetime of $\mathrm{C}_{2} \mathrm{H}_{6}$ in winter. Comparisons to observations are presented below for surface air (Figure 3), columns (Figure 4), and vertical profiles from aircraft (Figure 5).

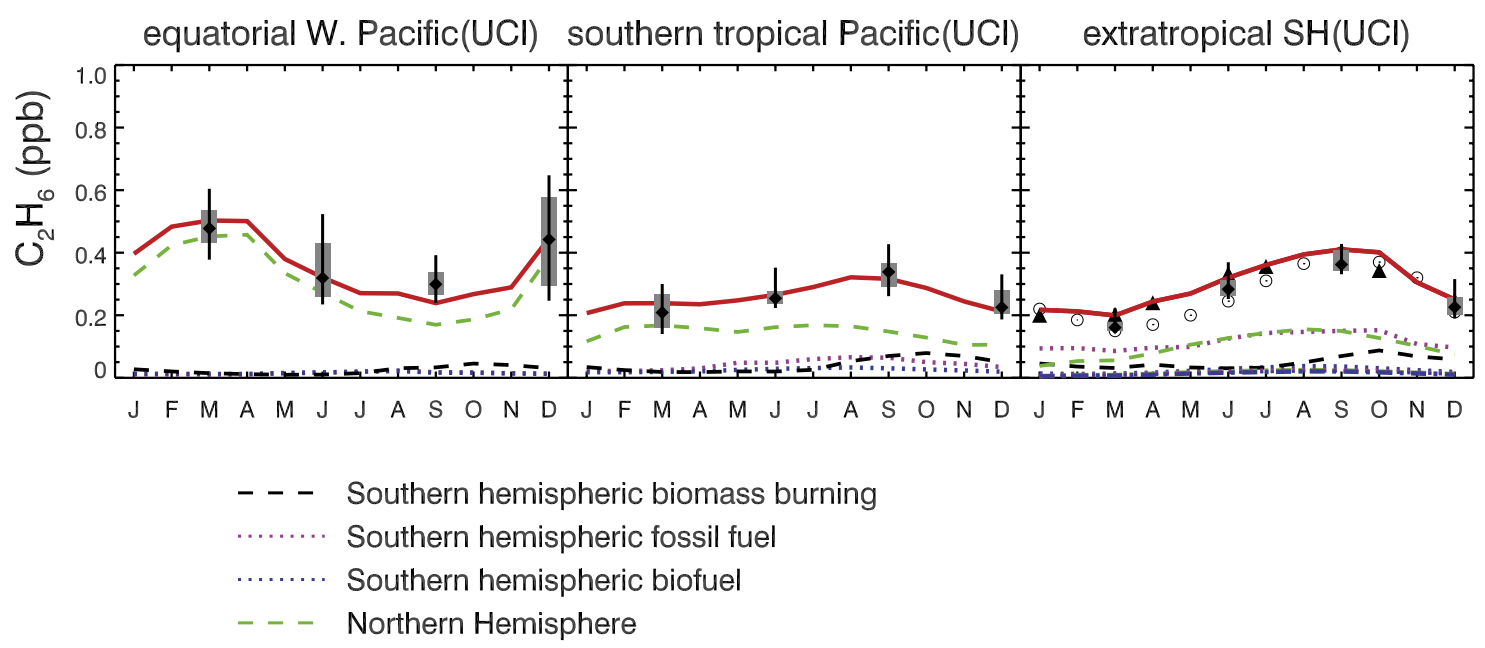

Figure 3b. Same as Figure 3a but for the equatorial western Pacific and the Southern Hemisphere and with different model source regions highlighted. Extratropical Southern Hemisphere data are from Baring Head (solid triangle) and Scott Base (open circle). Note change in scale relative to Figure 3a. 

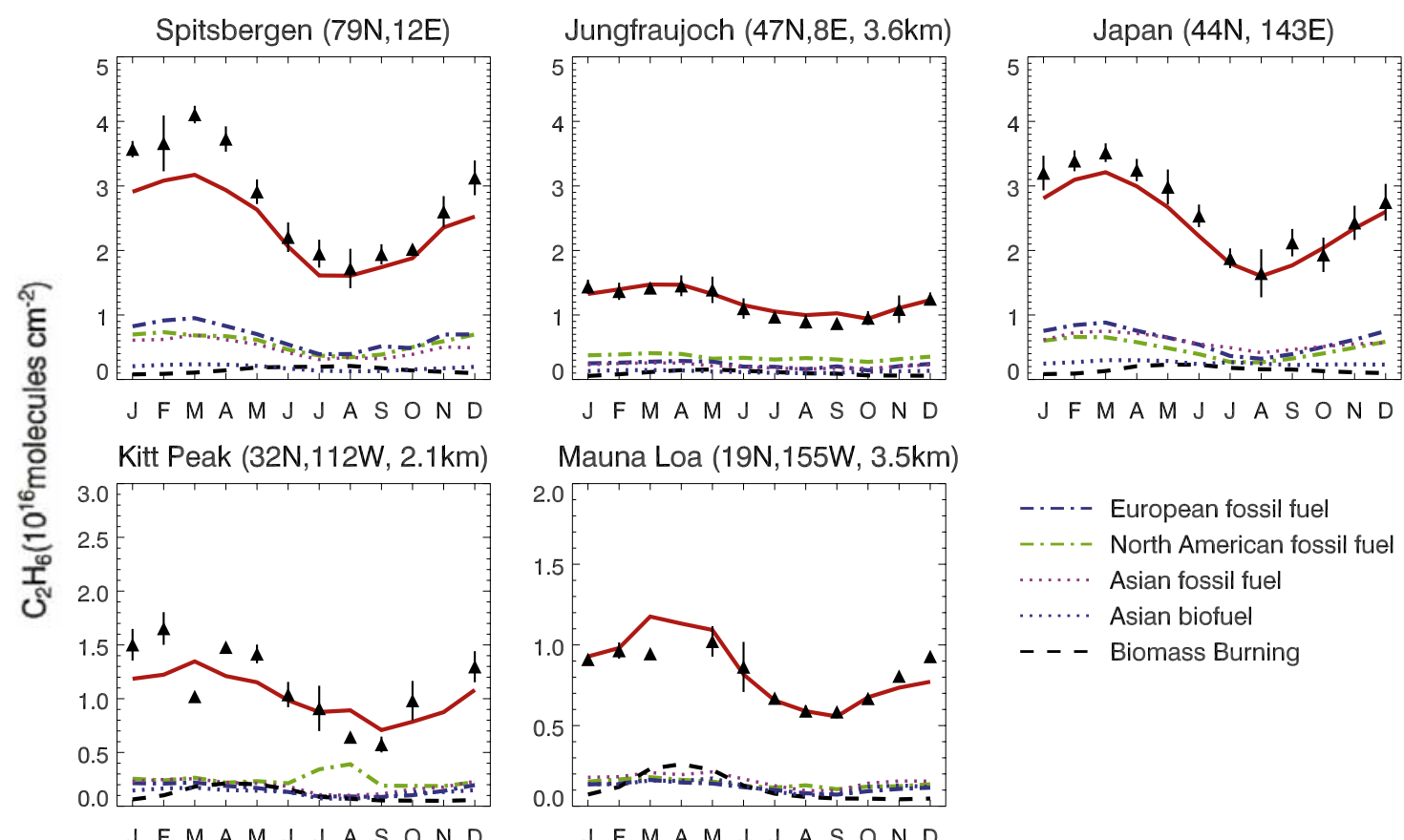

Figure 4a. Tropospheric $\mathrm{C}_{2} \mathrm{H}_{6}$ columns for the sites of Figure 1. Model values are shown in red. Observations (black) are from multiyear records (Table 3), and vertical bars are standard deviations for the monthly mean data in individual years. Also shown as dashed and dotted lines are contributions from major source types and regions to the model mixing ratios. Note the different scales between panels.

\subsection{Surface and Ground-Based Column Observations}

[21] Observations show similar values in the Arctic, Alaska, and the more remote northern European sites, with mixing ratios of $2-3 \mathrm{ppb}$ in winter and $0.8-1 \mathrm{ppb}$ in summer. The central European sites (south of $56^{\circ} \mathrm{N}$ ) are more polluted, with $\mathrm{C}_{2} \mathrm{H}_{6}$ mixing ratios greater than $3 \mathrm{ppb}$ in winter/spring. As shown in Figure 3a, the model reproduces the observations in Alaska and the Arctic but is too high by $30 \%$ over northern Europe and by $20 \%$ over central Europe; note that the model uses emissions from Europe that are $30 \%$ lower than those by Xiao et al. [2004], and emissions from Asia that are 30\% larger, to improve agreement over Europe, while maintaining a good simulation at remote northern locations and downwind of Asia.
The successful simulation of the seasonal amplitude implies a good description of the $\mathrm{C}_{2} \mathrm{H}_{6}$ sink [Goldstein et al., 1995]. Although the model overestimates the surface observations over Europe, the model agrees better with the column data over Jungfraujoch and Spitsbergen while it is too low at the latter by about $15 \%$ in winter (Figure $4 \mathrm{a}$ ); the European source provides a smaller fraction of $\mathrm{C}_{2} \mathrm{H}_{6}$ in the column than at the surface stations.

[22] Possible causes of the high bias at European surface sites include (1) an overestimate of the European source; (2) deficiencies in the boundary layer mixing in the model; and (3) a bias in estimating Asian sources of $\mathrm{C}_{2} \mathrm{H}_{6}$. We note that Asian fossil fuel and biofuel sources make substantial contributions to surface and column $\mathrm{C}_{2} \mathrm{H}_{6}$ at northern high latitudes, as shown in Figures $3 \mathrm{a}$ and $4 \mathrm{a}$,

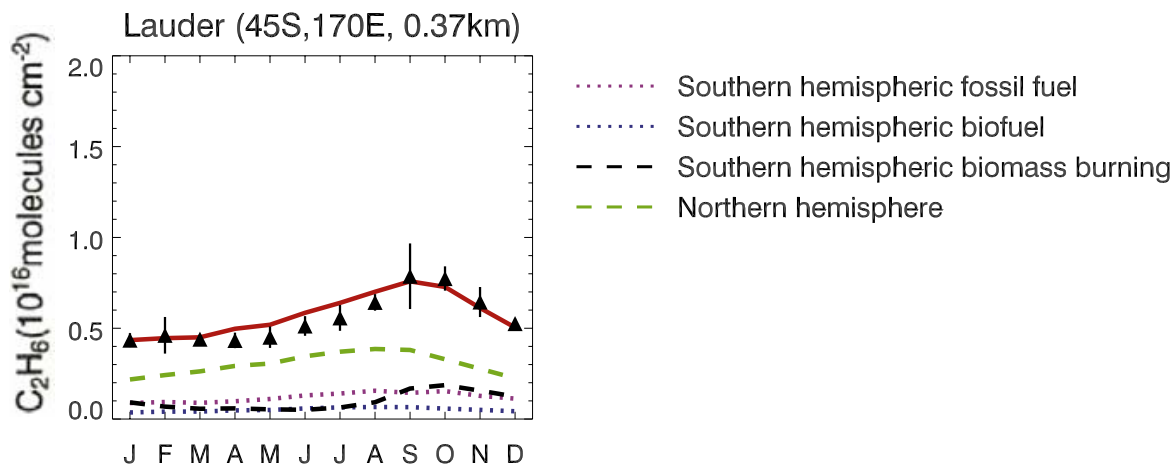

Figure 4b. Same as Figure 4a but for the Southern Hemisphere and with different model source regions highlighted. 

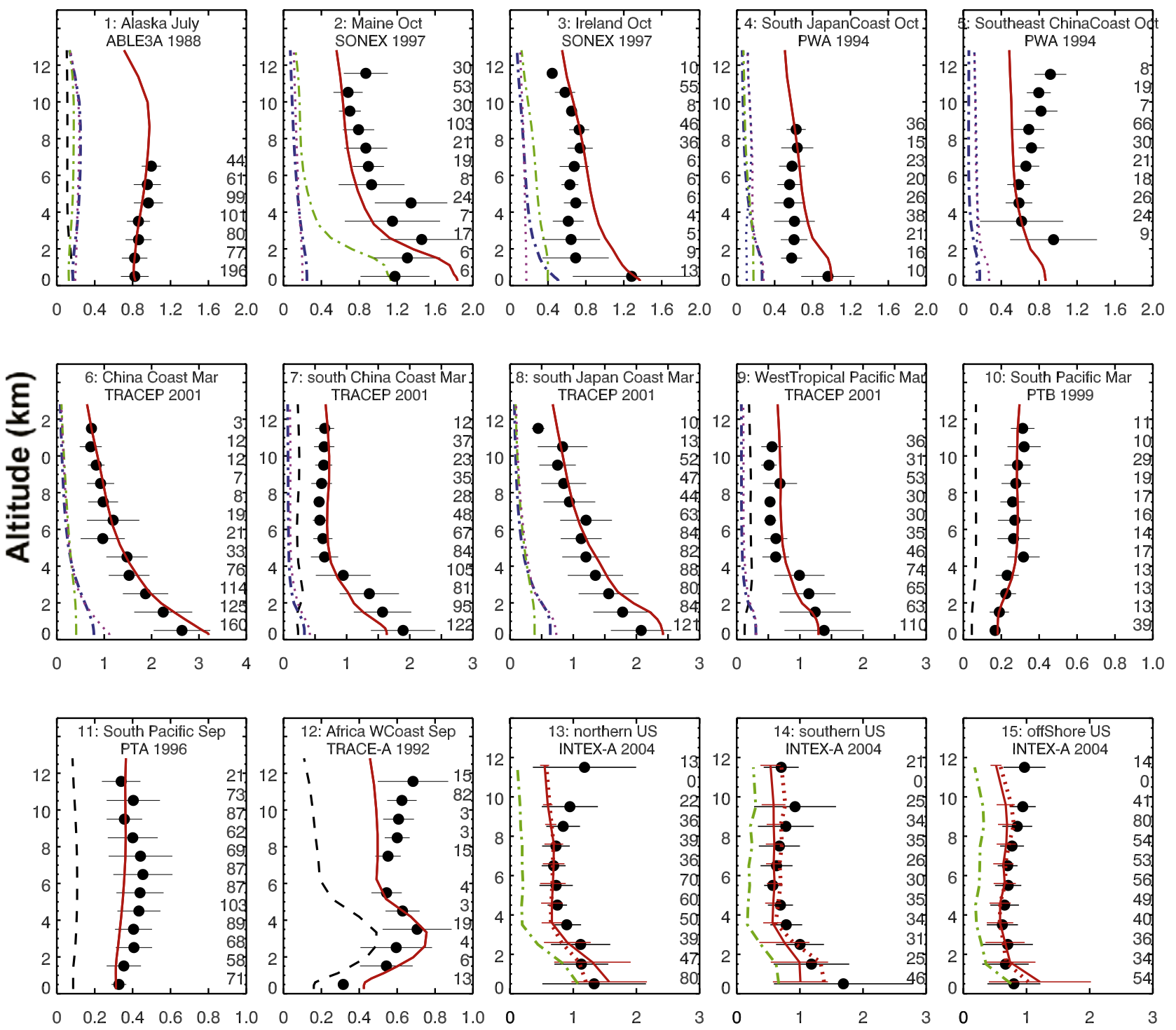

\section{$\mathrm{C}_{2} \mathrm{H}_{6}(\mathrm{ppb})$}

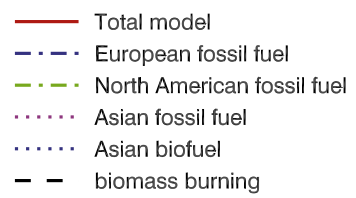

Figure 5. Vertical profiles of $\mathrm{C}_{2} \mathrm{H}_{6}$ for the regions in Figure 1 and Table 2. Symbols are mean observed values from aircraft missions. The standard deviations (horizontal bars) and number of observations per $1-\mathrm{km}$ bin are also shown. The model results (red lines) are monthly mean values for the flight regions, except for INTEX-A regions where the model results are sampled along the flight tracks (standard deviations in the model results are shown). Contributions from major sources in the model are also shown (see legend). The INTEX-A panels include results from the model simulation with optimized North American sources (dotted red line, see section 5). Note the differences in scales between panels.

similar in magnitude to the contribution from European fossil fuel sources. European and Asian fossil fuel sources make similar contributions to simulated $\mathrm{C}_{2} \mathrm{H}_{6}$ in the Asian outflow, as discussed below. A further decrease in the European source with a compensating increase in the Asian source would compromise the simulation of Asian outflow, as shown in Figure 5 below. More observations over continental Asia are necessary to further constrain the European and Asian sources of $\mathrm{C}_{2} \mathrm{H}_{6}$. The North American source is well constrained, as shown in section 5, and cannot be adjusted to compensate for a further decrease in the European source. 


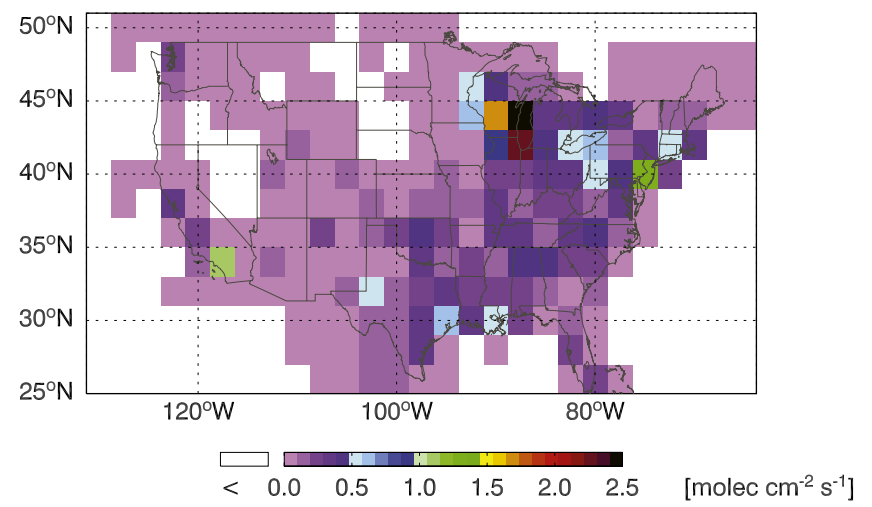

Figure 6. Mean July-August anthropogenic $\mathrm{C}_{2} \mathrm{H}_{6}$ emissions in the United States used for the model simulation of INTEX-A observations, taken from the U.S. EPA NEI-99 inventory and scaled up by a factor of 3.5.

[23] Good agreement is found between model and observations for the U.S. sites (Figure 3a), with the North American fossil fuel source contributing about half of the model values in the west, more in the east. The column measurements at Kitt Peak in Arizona $(2.1 \mathrm{~km})$ are reproduced by the model, although there the North American source is a minor contributor. A more detailed analysis of the North American source of $\mathrm{C}_{2} \mathrm{H}_{6}$ will be presented in section 5. The model agrees reasonably well with $\mathrm{C}_{2} \mathrm{H}_{6}$ column observations over Japan, but is slightly low in the first half of the year (Figure 4a).

[24] Observed and simulated $\mathrm{C}_{2} \mathrm{H}_{6}$ mixing ratios decrease from the northern midlatitudes to Hawaii, and further decrease to the equatorial western Pacific region. The relative seasonal amplitudes of $\mathrm{C}_{2} \mathrm{H}_{6}$ are the same from northern midlatitudes to the tropics with a maximum to minimum ratio of $2-2.5$, but the phase is delayed by one month for Hawaii and an additional month for the equatorial Pacific. This indicates a dominant source from northern midlatitudes propagating the seasonal signal. The anthropogenic sources from North America, Europe and Asia make similar contributions to the modeled $\mathrm{C}_{2} \mathrm{H}_{6}$ at the surface air and in the column over Hawaii (Mauna Loa in Figure 4b).

[25] Ethane values decline further from the equatorial western Pacific to the Southern Hemisphere, in the observations and the model, reflecting the continued dominance of the Northern Hemisphere source. The cross-equatorial $\mathrm{C}_{2} \mathrm{H}_{6}$ flux to the Southern Hemisphere is largest in northern hemispheric winter, as shown by the equatorial western Pacific data, but the $\mathrm{OH}$ sink in the Southern Hemisphere is also strongest then. This results in a reversed and dampened seasonal variation in the southern tropical Pacific relative to Hawaii, both in the model and in the observations (Figure 3b). In the extratropical Southern Hemisphere, the larger $\mathrm{OH}$ seasonal variation and the Southern Hemisphere biomass burning source combine to produce a spring maximum. Even at southern midlatitudes, the largest source of $\mathrm{C}_{2} \mathrm{H}_{6}$ is from the Northern Hemisphere, both at the surface (Figure $3 \mathrm{~b}$ ) and in the column over New Zealand (Figure 4b).

\subsection{Vertical Structure From Aircraft Missions}

[26] Figure 5 compares simulated and observed vertical profiles of $\mathrm{C}_{2} \mathrm{H}_{6}$ averaged over the regions shown in Figure 1. The aircraft observations are averages in $1 \mathrm{~km}$ vertical bands. Contributions from major $\mathrm{C}_{2} \mathrm{H}_{6}$ sources in the model (with a mean contribution $>15 \%$ ) are also shown.

[27] The observations over Alaska in July (ABLE-3A mission) show a slight increase with altitude, which is reproduced by the model and mainly reflects anthropogenic emissions transported from Europe and Asia following continental convection. Over Maine and Ireland (SONEX mission), the model is similar to the observations in the upper troposphere where most measurements were made, but is too high in the boundary layer where observations are few. As noted section 3, interannual variability may affect the aircraft comparisons. Penkett et al. [1993] reported $1.45-1.9 \mathrm{ppb}_{2} \mathrm{H}_{6}$ in the marine boundary layer off the coast of Ireland in October where they sampled air from the Arctic, while the observations in Figure 5 are a factor of 2 lower $(\sim 0.7 \mathrm{ppb})$ because of the influence of tropical marine air [Fuelberg et al., 2000]. The model reproduces the boundary layer enhancements of $\mathrm{C}_{2} \mathrm{H}_{6}$ in Asian outflow for the PEM-West A and TRACE-P missions over the northwest Pacific. European and Asian fossil fuel sources make similar contributions to simulated $\mathrm{C}_{2} \mathrm{H}_{6}$ in the outflow.

[28] Over the northern (region 13) and southern (region 14) United States during INTEX-A, observations of $\mathrm{C}_{2} \mathrm{H}_{6}$ show a decrease from the boundary layer to the free troposphere and then an increase above $8 \mathrm{~km}$ (see Figure 5). The model shows opposite biases for the two regions in the boundary layer and this will be addressed in section 5 . It does not capture the upper tropospheric enhancement, which reflects unexpectedly strong convective influence [Bertram et al., 2007].

[29] Ethane mixing ratios over the southern tropical Pacific in March (PEM-Tropics B mission) show an increase with altitude, both in the observations and the model, reflecting the transport of $\mathrm{C}_{2} \mathrm{H}_{6}$ from the Northern Hemisphere.. This reversed vertical gradient in the Southern Hemisphere for species originating in the Northern Hemisphere is well known [Jacob et al., 1987]. The same region in September (PEM-Tropics A mission) shows an enhancement in the middle troposphere (caused by biomass burning emissions [Blake et al., 1999]) that is lacking in the model. The biomass burning enhancement relative to background is much weaker in the model than observed in PEM-Tropics A for other hydrocarbons such as acetylene with shorter lifetimes and relatively stronger biomass burning sources [Xiao et al., 2007]. The PEM-Tropics observations show boundary layer $\mathrm{C}_{2} \mathrm{H}_{6}$ mixing ratios of $170 \mathrm{ppt}$ in March and $320 \mathrm{ppt}$ in September, consistent with the model and with the surface observations in the southern tropical Pacific in Figure 3b. The model underestimate of the biomass burning enhancement in the middle troposphere in PEM-Tropics A is due at least in part to interannual variability of transport, as shown by Xiao et al. [2007] in a comparison of 2001 and 1996 simulations for acetylene. The meteorology in 1996 was particularly favorable for transport of biomass burning effluents from Africa and South America to the South Pacific [Staudt et al., 2002]. It appears less likely that the model underestimates biomass burning emissions, since as shown in Figure 5 it 


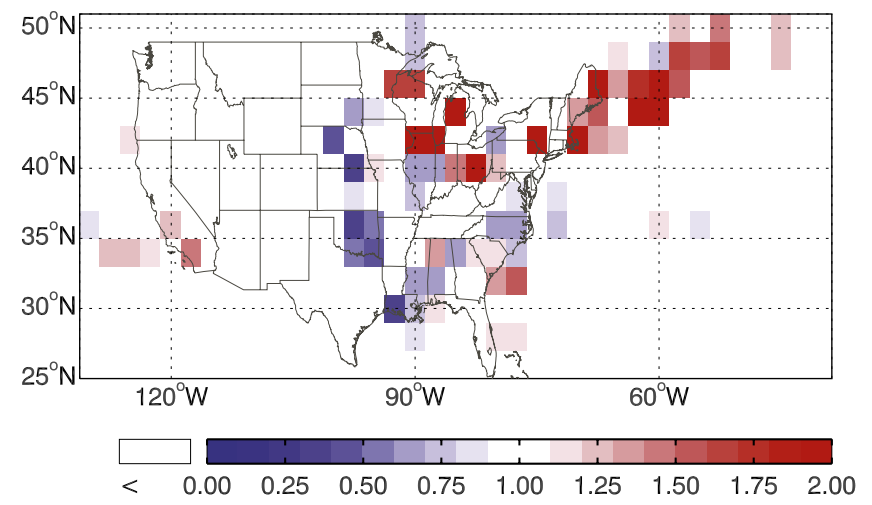

Figure 7. Median ratio of simulated-to-observed $\mathrm{C}_{2} \mathrm{H}_{6}$ mixing ratios below $2 \mathrm{~km}$ for the model with the NEI-99 inventory scaled up by a factor of 3.5. The observations are from the INTEX-A aircraft mission and are averaged over the model grid. Model values are sampled along the flight tracks for the days of the flights.

reproduces successfully the elevated observations over Africa in October (TRACE-A mission) under conditions of strong regional biomass burning influence.

\section{Constraints on $\mathrm{C}_{2} \mathrm{H}_{6}$ Emissions in the United States}

[30] The extensive measurements of $\mathrm{C}_{2} \mathrm{H}_{6}$ in the boundary layer over the central and eastern United States during the INTEX-A campaign (Figure 1) allow a more focused analysis of regional $\mathrm{C}_{2} \mathrm{H}_{6}$ sources. Figure 6 shows the spatial distribution of emissions assumed in the model, taken from the EPA NEI-99 inventory and scaled up by a factor of 3.5 as noted in section 2. The major source regions include the south-central states (Texas, Louisiana, Oklahoma), the Lake Michigan area (Illinois and Wisconsin), and large metropolitan areas (Los Angeles, New York City). The major $\mathrm{C}_{2} \mathrm{H}_{6}$ source types in the NEI-99 inventory are "industrial solvents" (47\%), which account for the Lake Michigan maximum, and "other industrial" (28\%) which includes natural gas/oil exploitation and accounts for the high values in south-central states. There are in addition minor sources from transportation, power plants, and residential fossil fuel. Ethane has no significant use as industrial solvent and this source attribution in the NEI-99 inventory is likely a result of the speciation profiles used to derive emissions of individual hydrocarbons.

[31] Figure 7 shows the geographical distribution of the median ratio of simulated-to-observed $\mathrm{C}_{2} \mathrm{H}_{6}$ mixing ratios below $2 \mathrm{~km}$. The observations are averaged over the model grid squares, and the model values are sampled along the INTEX-A flight tracks at the time of the flights. The model bias shows a distinct regional pattern, with a consistent overestimate in the northeast and offshore (east of $76^{\circ} \mathrm{W}$ and north of $41^{\circ} \mathrm{N}$, with a mean relative bias of 1.6), an overestimate for the Midwest (west of $76^{\circ} \mathrm{W}$ and north of $41^{\circ} \mathrm{N}$ with a bias of 1.3 ), and an underestimate in the southeast and south-central region (south of $41^{\circ} \mathrm{N}$ and for $76^{\circ}-105^{\circ} \mathrm{W}$, with a bias of 0.7$)$.
[32] We find from the tagged tracers in the model that the regional biases in Figure 7 can be corrected by decreasing the northern (the Midwest and northeast) U.S. source by $50 \%$ and doubling the southern U.S. source east of $105^{\circ} \mathrm{W}$ relative to our emission inventory in Figure 6 . Noting that our emission inventory is a factor of 3.5 higher than EPA NEI-99, these values are a factor of 1.8 and 7 higher than the corresponding values in the EPA NEI-99 inventory, for the northern and the southern region, respectively. The national emission total with this optimized source is similar to the original (2.4 vs. $\left.2.2 \mathrm{Tg} \mathrm{yr}^{-1}\right)$ but the distribution is very different, with $2.0 \mathrm{Tg} \mathrm{yr}^{-1}$ in the southeast and southcentral region, and $0.4 \mathrm{Tg} \mathrm{yr}^{-1}$ in the Midwest and northeast region. The largest source of $\mathrm{C}_{2} \mathrm{H}_{6}$ is then in the southern regions ( $\sim 80 \%$ of the national total). The regional source correction improves the model simulation not only in the boundary layer but also in the upper troposphere of the southern and offshore regions (Figure 5, dotted red line).

\section{Discussion and Conclusions}

[33] As the second most abundant constituent of natural gas after methane, $\mathrm{C}_{2} \mathrm{H}_{6}$ is a valuable tracer of fossil fuel production rather than combustion. We have evaluated a process-based emission inventory for $\mathrm{C}_{2} \mathrm{H}_{6}$ with a global model simulation of a large worldwide data set of observations from surface sites (including column measurements) and aircraft missions. Our primary motivation was to develop the potential of observed correlations of $\mathrm{CH}_{4}$ $\mathrm{C}_{2} \mathrm{H}_{6}$, when interpreted with a CTM, as constraints on the fossil fuel source of $\mathrm{CH}_{4}$.

[34] Our estimate of global $\mathrm{C}_{2} \mathrm{H}_{6}$ emissions is $13 \mathrm{Tg} \mathrm{yr}^{-1}$ including 8.0 $\mathrm{Tg} \mathrm{yr}^{-1}$ from fossil fuels, $2.6 \mathrm{Tg} \mathrm{yr}^{-1}$ from biofuel, and $2.4 \mathrm{Tg} \mathrm{yr}^{-1}$ from biomass burning, as compared to the range of $8-18 \mathrm{Tg} \mathrm{yr}^{-1}$ for the global $\mathrm{C}_{2} \mathrm{H}_{6}$ source in previous literature estimates. Our global budget is for the decade of the 1990s, the period of most observations used to constrain sources (see Table 3). We reduced the European source of $\mathrm{C}_{2} \mathrm{H}_{6}$ by $30 \%$ relative to Xiao et al. [2004], and compensated with a $30 \%$ increase in the Asian source to maintain a good simulation of $\mathrm{C}_{2} \mathrm{H}_{6}$ at remote northern locations and downwind of Asia. The fossil fuel sources of $\mathrm{C}_{2} \mathrm{H}_{6}$ from the major continental regions of Europe, North America and Asia are of similar magnitude, and they contribute about equally to surface and column $\mathrm{C}_{2} \mathrm{H}_{6}$ in the Arctic.

[35] The source from biofuel is larger than that for biomass burning, even though the amount of dry matter burned for biofuel is much smaller, because the emission factor for the former is more than twice the average value for the latter.

[36] The source strength of $\mathrm{C}_{2} \mathrm{H}_{6}$ in the Southern Hemisphere is $20 \%$ of that in the Northern Hemisphere, sufficiently small that transport from the north is an important source of $\mathrm{C}_{2} \mathrm{H}_{6}$ throughout the Southern Hemisphere, providing $1.7 \mathrm{Tg} \mathrm{yr}^{-1}$. Within the Southern Hemisphere, the largest source is biomass burning $\left(1.0 \mathrm{Tg}^{-1}\right)$, with smaller sources from fossil fuels $\left(0.6 \mathrm{Tg} \mathrm{yr}^{-1}\right)$ and biofuel $\left(0.5 \mathrm{Tg} \mathrm{yr}^{-1}\right)$.

[37] The model is generally successful in reproducing the magnitude, seasonal variation, and vertical distribution of $\mathrm{C}_{2} \mathrm{H}_{6}$ shown by surface and aircraft measurements. The 
Table 4. Implied Source of $\mathrm{C}_{2} \mathrm{H}_{6}$ in the U.S. for a $\mathrm{CH}_{4}$ Source of $10 \mathrm{Tg} \mathrm{yr}^{-1}$ From Fossil Fuel Production ${ }^{\mathrm{a}}$

\begin{tabular}{|c|c|c|c|c|}
\hline & \multicolumn{3}{|c|}{$\mathrm{CH}_{4} / \mathrm{C}_{2} \mathrm{H}_{6}$ Ratios (Molar) } & \multirow{2}{*}{$\begin{array}{c}\text { Implied } \mathrm{C}_{2} \mathrm{H}_{6} \\
\text { Emissions }\left(\mathrm{Tg} \mathrm{yr}^{-1}\right)^{\mathrm{b}}\end{array}$} \\
\hline & Natural Gas & Oil & Coal Mines & \\
\hline Case 1 & 20 & 4 & 10 & 1.8 \\
\hline Case $2^{\mathrm{c}}$ & 19 & 7 & 10 & 1.5 \\
\hline Case $3^{\mathrm{d}}$ & 19 & 7 & 100 & 1.0 \\
\hline Typical values ${ }^{\mathrm{e}}$ & $\begin{array}{l}20-100 \text { dry gas, } \\
10-20 \text { gas condensate }\end{array}$ & $4-10$ & $\begin{array}{l}\sim 10 \text { thermogenic origin, } \\
>200 \text { biogenic origin }\end{array}$ & \\
\hline
\end{tabular}

${ }^{\mathrm{a}}$ We assumed that $55 \%$ of $\mathrm{CH}_{4}$ is from natural gas production, $30 \%$ from coal mining, and $15 \%$ from petroleum systems and that $75 \%$ of natural gas production is from gas wells and $25 \%$ from oil wells.

${ }^{\mathrm{b}} \mathrm{This}$ is as compared to our estimate of $2.4{\mathrm{Tg} \mathrm{yr}^{-1}}^{-1}$

${ }^{\mathrm{c}}$ Ratios for natural gas and oil are from Katzenstein et al. [2003].

${ }^{\mathrm{d}}$ This is assuming at least half of gas from coal mines is of biogenic origin

e Values are from Jones et al. [1999] and Strapoć et al. [2007].

major model bias is an overestimate of $30 \%$ at European stations. The model reproduces the relative seasonal amplitudes of $\mathrm{C}_{2} \mathrm{H}_{6}$ at northern midlatitudes and in the northern tropics and of $\mathrm{C}_{2} \mathrm{H}_{2}$ [Xiao et al., 2007], lending confidence to the simulation of the $\mathrm{C}_{2} \mathrm{H}_{6}$ sink [Goldstein et al., 1995]. The model interpretation of observations in the tropics and Southern Hemisphere confirms the dominant role of northern midlatitudes as a worldwide source of $\mathrm{C}_{2} \mathrm{H}_{6}$.

[38] The $\mathrm{OH}$ distribution used in our analysis corresponds to lifetime for methylchloroform in the troposphere of 6.3 years. A new assessment of uncertainties in mean $\mathrm{OH}$ derived from methylchloroform observations gives a range for the lifetime of 5.6-6.9 years [Wang et al., 2008]. This range suggests that the error in our model mean $\mathrm{OH}$ is $\pm 10 \%$, or an error of $\pm 1.3 \mathrm{Tg} \mathrm{yr}^{-1}$ for $\mathrm{C}_{2} \mathrm{H}_{6}$ emissions. Our budget is based on one year of model $\mathrm{OH}$ values. Interannual variability in mean $\mathrm{OH}$ in 3 -D models is less than $\pm 5 \%$ [e.g., Dentener et al., 2003; Wang et al., 2004; Duncan and Logan, 2008], and this is not a major source of error in our estimate for $\mathrm{C}_{2} \mathrm{H}_{6}$ emissions.

[39] Ethane emissions in the United States are underestimated in the national emissions inventory for 1999 (NEI-99). Our standard simulation retained the spatial distribution of NEI-99 but used the $\mathrm{C}_{2} \mathrm{H}_{6}$ source of $2.2 \mathrm{Tg}$ $\mathrm{yr}^{-1}$ as compared to $0.6 \mathrm{Tg} \mathrm{yr}^{-1}$ in NEI-99. We tested it by comparison with extensive aircraft observations of $\mathrm{C}_{2} \mathrm{H}_{6}$ in the boundary layer over the central and eastern United States in July-August 2004 during the INTEX-A campaign. We found that fitting the INTEX-A aircraft data requires a factor of 7 increase in NEI-99 emissions for the United States south of $41^{\circ} \mathrm{N}$, where the dominant source is from the natural gas industry, and a factor of 1.8 increase for the northern United States, where the dominant source was ascribed to industrial solvents. Our revised estimate for the U.S. source of $\mathrm{C}_{2} \mathrm{H}_{6}$ is $2.4 \mathrm{Tg} \mathrm{yr}^{-1}$. The NEI inventory relies on speciation profiles that are applied to emissions of hydrocarbons from various processes, and these appear to be inappropriate for $\mathrm{C}_{2} \mathrm{H}_{6}$ which does not belong in the solvents category.

[40] We now address whether bottom-up estimates of $\mathrm{CH}_{4}$ emissions from energy production in the U.S. are consistent with our estimate of $\mathrm{C}_{2} \mathrm{H}_{6}$ emissions in the U.S. The national inventories for $\mathrm{CH}_{4}$ from fossil fuels give a source of $11.2 \mathrm{Tg} \mathrm{yr}^{-1}$ [EIA, 2007] and $9.5 \mathrm{Tg} \mathrm{yr}^{-1}$ [EPA, 2008 ] for 2004, with 55\% from natural gas production, $30 \%$ from coal mining, and $15 \%$ from petroleum systems. In the U.S., $75 \%$ of natural gas production is from gas wells, and the rest from oil wells [http://www.eia.doe.gov/neic/quickfacts/ quickgas.html]. Table 4 shows the $\mathrm{C}_{2} \mathrm{H}_{6}$ emissions implied by a $\mathrm{CH}_{4}$ source of $10 \mathrm{Tg} \mathrm{yr}^{-1}$, with various assumptions about $\mathrm{CH}_{4} / \mathrm{C}_{2} \mathrm{H}_{6}$ ratios (molar). Case 1 assumes lower limits for these ratios, and gives an $\mathrm{C}_{2} \mathrm{H}_{6}$ source of $\sim 2 \mathrm{Tg} \mathrm{yr}^{-1}$, similar to our estimate of $2.4 \mathrm{Tg} \mathrm{yr}^{-1}$. Case 2 assumes that the ratios derived by Katzenstein et al. [2003] downwind of natural gas and oil storage tanks are appropriate for the entire U.S., and that all coalbed gas is of thermogenic origin (ratio $=10$ ); this gives an $\mathrm{C}_{2} \mathrm{H}_{6}$ source of $1.5 \mathrm{Tg} \mathrm{yr}^{-1}$, implying that a $\mathrm{CH}_{4}$ source of $10 \mathrm{Tg} \mathrm{yr}^{-1}$ is too small by $50 \%$. Case 3 is similar to Case 2, but assumes that half of coalbed $\mathrm{CH}_{4}$ is of biogenic origin) and gives an $\mathrm{C}_{2} \mathrm{H}_{6}$ source of $1.0 \mathrm{Tg} \mathrm{yr}{ }^{-1}$, implying that the $\mathrm{CH}_{4}$ source is $>20 \mathrm{Tg} \mathrm{yr}^{-1}$. Clearly, adopting larger ratios for $\mathrm{CH}_{4} / \mathrm{C}_{2} \mathrm{H}_{6}$ would imply even larger estimates for the U.S. source of $\mathrm{CH}_{4}$ from energy production. We note that the inverse analysis of $\mathrm{CH}_{4}$ observations of Wang et al. [2008] gave a source of $20 \mathrm{Tg} \mathrm{yr}^{-1}$ associated with energy production in the U.S.

[41] Our estimate of $\mathrm{C}_{2} \mathrm{H}_{6}$ emissions of $2.4 \mathrm{Tg} \mathrm{yr}^{-1}$, constrained by INTEX-A observations, is consistent with the national inventories for $\mathrm{CH}_{4}$ from energy production $\left(\sim 10 \mathrm{Tg} \mathrm{yr}^{-1}\right)$ only if we assume lower limits for $\mathrm{CH}_{4} / \mathrm{C}_{2} \mathrm{H}_{6}$ ratios. It appears likely that $\mathrm{CH}_{4}$ emissions in this category are underestimated by as much as $50-100 \%$. More atmospheric observations of $\mathrm{CH}_{4} / \mathrm{C}_{2} \mathrm{H}_{6}$ mixing ratios downwind of major sources categories would improve constraints on the $\mathrm{CH}_{4}$ source based on the $\mathrm{C}_{2} \mathrm{H}_{6}$ budget. With such observations, a formal inverse analysis of the $\mathrm{C}_{2} \mathrm{H}_{6}-\mathrm{CH}_{4}$ system with a CTM would lead to improved constraints on top down emission estimates for both gases.

[42] Acknowledgments. We thank Steven Wofsy and Michael McElroy for their insightful comments. This work was supported by the U.S. National Science Foundation and by the NASA/GTE program.

\section{References}

Andreae, M. O., and P. Merlet (2001), Emission of trace gases and aerosols from biomass burning, Global Biogeochem. Cycles, 15(4), 955-966.

Atkinson, R. (2000), Atmospheric chemistry of VOCs and NOx, Atmos. Environ., 34, 2063-2101.

Bartlett, K. B., G. W. Sachse, J. E. Collins, and R. C. Harriss (1996), Methane in the tropical South Atlantic: Sources and distribution during the late dry season, J. Geophys. Res., 101(D19), 24,139-24,150.

Bartlett, K. B., G. W. Sachse, T. Slate, C. Harward, and D. B. Blake (2003), Large-scale distribution of $\mathrm{CH}_{4}$ in the western North Pacific: Sources and transport from the Asian continent, J. Geophys. Res., 108(D20), 8807, doi:10.1029/2002JD003076. 
Barletta, B., S. Meinardi, F. S. Rowland, C. Y. Chan, X. M. Wang, S. C. Zou, L. Y. Chan, and D. R. Blake (2005), Volatile organic compounds in 43 Chinese cities, Atmos. Environ., 39(32), 5979-5990.

Bertram, T., et al. (2007), Direct measurements of the convective recycling of the upper troposphere, Science, 315,816-820, doi:10.1126/ science. 1134548 .

Bertschi, I. T., R. J. Yokelson, D. E. Ward, T. J. Christian, and W. M. Hao (2003), Trace gas emissions from the production and use of domestic biofuels in Zambia measured by open-path Fourier transform infrared spectroscopy, J. Geophys. Res., 108(D13), 8469, doi:10.1029/2002JD002158.

Bey, I., D. J. Jacob, R. M. Yantosca, J. A. Logan, B. Field, A. M. Fiore, Q. Li, H. Liu, L. J. Mickley, and M. Schultz (2001), Global modeling of tropospheric chemistry with assimilated meteorology: Model description and evaluation, J. Geophys. Res., 106(D19), 23,073-23,096.

Blake, D. R. (2005), Methane, nonmethane hydrocarbons, alkyl nitrates, and chlorinated carbon compounds including 3 chlorofluorocarbons (CFC-11, CFC-12, and CFC-113) in whole-air samples, in Trends: $A$ Compendium of Data on Global Change, Carbon Dioxide Information Analysis Center, Oak Ridge National Laboratory, U.S. Department of Energy, Oak Ridge, Tenn

Blake, D. R., and F. S. Rowland (1986), Global atmospheric concentrations and source strength of ethane, Nature, 321, 231-233.

Blake, D. R., T. Y. Chen, T. Y. Smith, C. J. L. Wang, O. W. Wingenter, N. J. Blake, F. S. Rowland, and E. W. Mayer (1996), Three-dimensional distribution of nonmenthane hydrocarbons and halocarbons over the northwestern Pacific during the 1991 Pacific Exploratory Mission (PEM-West A), J. Geophys. Res., 101(D1), 1763-1778.

Blake, N. J., et al. (1999), Influence of southern hemispheric biomass burning on midtropospheric distributions of nonmethane hydrocarbons and selected halocarbons over the remote South Pacific, J. Geophys. Res., 104(D13), 16,213-16,232.

Boissard, C., B. Bonsang, M. Kanakidou, and G. Lambert (1996), TROPOZ II: Global distributions of budgets of methane and light hydrocarbons, J. Atmos. Chem., 25, 115-148.

Clarkson, T. S., R. J. Martin, and J. Rudolph (1997), Ethane and propane in the southern marine troposphere, Atmos. Environ., 31(22), 3763-3771.

Dentener, F., W. Peters, M. Krol, M. van Weele, P. Bergamaschi, and J. Lelieveld (2003), Interannual variability and trend of CH4 lifetime as a measure for $\mathrm{OH}$ changes in the 1979-1993 time period, J. Geophys. Res., 108(D15), 4442, doi:10.1029/2002JD002916.

Duncan, B. N., and J. A. Logan (2008), Model analysis of the factors regulating the trends and variability of carbon monoxide between 1988 and 1997, Atmos. Chem. Phys. Discuss., 8, 9099-9138.

Duncan, B. N., R. V. Martin, A. C. Staudt, R. Yevich, and J. A. Logan (2003), Interannual and seasonal variability of biomass burning emissions constrained by satellite observations, J. Geophys. Res., 108(D2), 4040, doi:10.1029/2002JD002378.

Duncan, B. N., J. A. Logan, I. Bey, I. A. Megretskaia, R. M. Yantosca, P. C. Novelli, N. B. Jones, and C. P. Rinsland (2007), Global budget of CO, 1988-1997: Source estimates and validation with a global model, J. Geophys. Res., 112, D22301, doi:10.1029/2007JD008459.

Energy Information Administration (2007), Emissions of Greenhouse Gases in the United States, Report of the Energy Information Administration (EIA), U.S. Department of Energy. (Available at http://www.eia.doe.gov/ oiaf/1605/ggrpt/index.html)

Environmental Protection Agency (2008), U.S. Greenhouse Gas Inventory Reports. (Available at http://epa.gov/climatechange/emissions/ usinventoryreport.html)

Fiore, A. M., D. J. Jacob, H. Liu, R. M. Yantosca, T. D. Fairlie, and Q. Li (2003), Variability in surface ozone background over the United States: Implications for air quality policy, J. Geophys. Res., 108(D24), 4787, doi:10.1029/2003JD003855.

Fuelberg, H. E., J. R. Hannan, P. F. J. van Velthoven, E. V. Browell, G. Bieberbach Jr., R. D. Knabb, G. L. Gregory, K. E. Pickering, and H. B. Selkirk (2000), A meteorological overview of the SONEX period, J. Geophys. Res., 105(D3), 3633-3651.

Fung, I., J. John, J. Lerner, E. Matthews, M. Prather, L. P. Steele, and P. J. Fraser (1991), Three-dimensional model synthesis of the global methane cycle, J. Geophys. Res., 96(D7), 13,033-13,065.

Gautrois, M., T. Brauers, R. Koppmann, F. Rohrer, O. Stein, and J. Rudolph (2003), Seasonal variability and trends of volatile organic compounds in the lower polar troposphere, J. Geophys. Res., 108(D13), 4393, doi:10.1029/2002JD002765.

Gnauk, T., and W. Rolle (1998), A three year study of nonmethane hydrocarbons in surface air over Saxony (Germany), J. Atmos. Chem., 30(2), 371 .

Goldstein, A. H., S. C. Wofsy, and C. M. Spivakovsky (1995), Seasonal variations of nonmethane hydrocarbons in rural New England: Constraints on $\mathrm{OH}$ concentrations in northern midlatitudes, J. Geophys. Res., 100(D10), 21,023-21,033.
Gupta, M. L., R. J. Cicerone, D. R. Blake, F. S. Rowland, and I. S. A. Isaksen (1998), Global atmospheric distributions and source strengths of light hydrocarbons and tetrachloroethene, J. Geophys. Res., 103, $28,219-28,235$

Harriss, R. C., et al. (1992), The Arctic Boundary Layer Expedition (ABLE 3A): July-August 1988, J. Geophys. Res., 97(D15), 16,383-16,394.

Hoell, J. M., D. Davis, S. C. Liu, R. Newell, M. Shipham, H. Akimoto, R. J. McNeal, R. J. Bendura, and J. W. Drewry (1996), Pacific exploratory Mission-West A (PEM-West A): September-October 1991, J. Geophys. Res., 101(D1), 1641-1653.

Hoell, J. M., D. D. Davis, D. J. Jacob, M. O. Rodgers, R. E. Newell, H. E. Fuelberg, R. J. McNeal, J. L. Raper, and R. J. Bendura (1999), Pacific Exploratory Mission in the tropical Pacific: PEM-Tropics A, AugustSeptember 1996, J. Geophys. Res., 104(D5), 5567-5583.

Jacob, D. J., M. J. Prather, S. C. Wofsy, and M. McElroy (1987), Atmospheric distribution of $\mathrm{Kr}-85$ simulated with a general-circulation model, J. Geophys. Res., 92(D6), 6614-6626.

Jacob, D. J., J. H. Crawford, M. M. Kleb, V. S. Connors, R. J. Bendura, J. L. Raper, G. W. Sachse, J. C. Gille, L. Emmons, and C. L. Heald (2003), The Transport and Chemical Evolution over the Pacific (TRACEP) aircraft mission: Design, execution, and first results, J. Geophys. Res., 108(D20), 9000, doi:10.1029/2002JD003276.

Jobson, B. T., H. Niki, Y. Yokouchi, J. Bottenheim, F. Hopper, and R. Leaitch (1994), Measurements of $\mathrm{C}_{2}-\mathrm{C}_{6}$ hydrocarbons during the Polar Sunrise 1992 Experiment: Evidence for $\mathrm{Cl}$ atom and $\mathrm{Br}$ atom chemistry, J. Geophys. Res., 99(D12), 25,355-25,368.

Jones, V. T., III, M. D. Matthews, and D. M. Richers (1999), Light hydrocarbons for petroleum and gas prospecting, in Geochemical Remote Sensing of the Subsurface, Handbook of Exploration Geochemistry, vol. 7 , edited by G. J. S. Govett and M. Hale, Elsevier, New York.

Kanakidou, M., H. B. Singh, K. M. Valentin, and P. J. Crutzen (1991), A 2-dimensional study of ethane and propane oxidation in the troposphere, J. Geophys. Res., 96(D8), 15,395-15,413.

Kasibhatla, P. S., H. Levy II, and W. J. Moxim (1993), Global $\mathrm{NO}_{x}, \mathrm{HNO}_{3}$, PAN, and $\mathrm{NO}_{y}$ distributions from fossil fuel combustion emissions: A model study, J. Geophys. Res., 98(D4), 7165-7180.

Katzenstein, A. S., L. A. Doezema, I. J. Simpson, D. R. Blake, and F. S. Rowland (2003), Extensive regional atmospheric hydrocarbon pollution in the southwestern United States, Proc. Natl. Acad. Sci. U.S.A., 100(21), 11,975-11,979.

Laurila, T., and H. Hakola (1996), Seasonal cycle of $\mathrm{C}_{2}-\mathrm{C}_{5}$ hydrocarbons over the Baltic Sea and Northern Finland, Atmos. Environ., 30(10-11), $1597-1607$.

Lindskog, A., and J. Moldanova (1994), The influence of the origin, season and time of the day on the distribution of individual NMHC measured at Rorvik, Sweden, Atmos. Environ., 28(15), 2383-2398.

Mahieu, E., R. Zander, L. Delbouille, P. Demoulin, G. Roland, and C. Servais (1997), Observed trends in total vertical column abundances of atmospheric gases from IR solar spectra recorded at the Jungfraujoch, J. Atmos. Chem., 28(1-3), 227-243.

Na, K., Y. P. Kim, I. Moon, and K. C. Moon (2004), Chemical composition of major VOC emission sources in the Seoul atmosphere, Chemosphere, 55(4), 585-594.

Nelson, P. F., S. H. Quigley, and M. Y. Smith (1983), Sources of atmospheric hydrocarbons in Sidney: A quantitative determination using a source reconciliation technique, Atmos. Environ., 17, 439-449.

Notholt, J., G. Toon, F. Stordal, S. Solberg, N. Schmidbauer, E. Becker, A. Meier, and B. Sen (1997), Seasonal variations of atmospheric trace gases in the high Arctic at $79^{\circ} \mathrm{N}$, J. Geophys. Res., 102(D11), 12,85512,861 .

Olivier, J. G. J., A. F. Bouwman, C. W. M. van der Maas, J. J. M. Berdowski, C. Veldt, J. P. J. Bloos, A. J. H. Visschedijk, P. Y. J. Zandveld, and J. L. Haverlag (1996), Description of EDGAR Version 2.0: A Set of Global Emission Inventories of Greenhouse Gases and Ozone-Depleting Substances for All Anthropogenic and Most Natural Sources on a Per Country Basis and on $1^{\circ} \times 1^{\circ}$ Grid, 141 pp., Natl. Inst. of Public Health and the Environ., Bilthoven, Netherlands.

Penkett, S. A., N. J. Blake, P. Lightman, A. R. W. Marsh, P. Anwyl, and G. Butcher (1993), The seasonal variation of nonmethane hydrocarbons in the free troposphere over the North Atlantic Ocean: Possible evidence for extensive reaction of hydrocarbons with the nitrate radical, J. Geophys. Res., 98(D2), 2865-2885.

Pfister, G., P. G. Hess, L. K. Emmons, J.-F. Lamarque, C. Wiedinmyer, D. P. Edwards, G. Pétron, J. C. Gille, and G. W. Sachse (2005), Quantifying CO emissions from the 2004 Alaskan wildfires using MOPITT CO data, Geophys. Res. Lett., 32, L11809, doi:10.1029/2005GL022995.

Piccot, S., J. Watson, and J. Jones (1992), A global inventory of volatile organic compound emissions from anthropogenic sources, J. Geophys. Res., 97(D9), 9897-9912. 
Plass-Dülmer, C., R. Koppmann, M. Ratte, and J. Rudolph (1995), Light nonmethane hydrocarbons in seawater, Global Biogeochem. Cycles, 9(1), $79-100$.

Prinn, R. G., et al. (2005), Evidence for variability of atmospheric hydroxyl radicals over the past quarter century, Geophys. Res. Lett., 32, L07809, doi:10.1029/2004GL022228.

Raper, J. L., M. M. Kleb, D. J. Jacob, D. D. Davis, R. E. Newell, H. E. Fuelberg, R. J. Bendura, J. M. Hoell, and R. J. McNeal (2001), Pacific Exploratory Mission in the tropical Pacific: PEM-Tropics B, MarchApril 1999, J. Geophys. Res., 106(D23), 32,401-32,425.

Rinsland, C. P., et al. (1998), Northern and Southern Hemisphere groundbased infrared spectroscopic measurements of tropospheric carbon monoxide and ethane, J. Geophys. Res., 103(D21), 28,197-28,217.

Rinsland, C. P., et al. (1999), Infrared solar spectroscopic measurements of free tropospheric $\mathrm{CO}, \mathrm{C}_{2} \mathrm{H}_{6}$, and $\mathrm{HCN}$ above Mauna Loa, Hawaii: Seasonal variations and evidence for enhanced emissions from the Southeast Asian tropical fires of 1997-1998, J. Geophys. Res., 104(D15), $18,667-18,680$.

Rinsland, C. P., N. B. Jones, B. J. Connor, S. W. Wood, A. Goldman, T. M. Stephen, F. J. Murcray, L. S. Chiou, R. Zander, and E. Mahieu (2002), Multiyear infrared solar spectroscopic measurements of $\mathrm{HCN}, \mathrm{CO}, \mathrm{C}_{2} \mathrm{H}_{6}$, and $\mathrm{C}_{2} \mathrm{H}_{2}$ tropospheric columns above Lauder, New Zealand $\left(45^{\circ} \mathrm{S}\right.$ latitude), J. Geophys. Res., 107(D14), 4185, doi:10.1029/2001JD001150.

Rudolph, J. (1995), The tropospheric distribution and budget of ethane, J. Geophys. Res., 100(D6), 11,369-11,381.

Rudolph, J., R. Koppmann, and C. PlassDulmer (1996), The budgets of ethane and tetrachloroethene: Is there evidence for an impact of reactions with chlorine atoms in the troposphere?, Atmos. Environ., 30(10-11), $1887-1894$.

Sander, S. P., et al. (2003), Chemical kinetics and photochemical data for use in atmospheric studies, Evaluation 14, NASA JPL.

Schneider, H. R., D. B. A. Jones, M. B. McElroy, and G.-Y. Shi (2000), Analysis of residual mean transport in the stratosphere. 1: Model description and comparison with satellite data, J. Geophys. Res., 105(D15), 19,991-20,012.

Shipham, M. C., P. M. Crill, K. B. Bartlett, A. H. Goldstein, P. M. Czepiel, R. C. Harriss, and D. Blaha (1998), Methane measurements in central New England: An assessment of regional transport from surrounding sources, J. Geophys. Res., 103(D17), 21,985-22,000.

Simpson, I. J., F. S. Rowland, S. Meinardi, and D. R. Blake (2006), Influence of biomass burning during recent fluctuations in the slow growth of global tropospheric methane, Geophys. Res. Lett., 33, L22808, doi:10.1029/2006GL027330.

Singh, H. B., and P. L. Hanst (1981), Peroxyacetyl nitrate (PAN) in the unpolluted atmosphere: An important reservoir for nitrogen oxides, Geophys. Res. Lett., 8(8), 941-944.

Singh, H. B., and P. B. Zimmerman (1992), Atmospheric distribution and sources of nonmethane hydrocarbons, in Gaseous Pollutants: Characterization and Cycling, edited by J. O. Nriagu, pp. 177-235, John Wiley, New York.

Singh, H. B., et al. (1996), Low ozone in the marine boundary payer of the tropical Pacific Ocean: Photochemical loss, chlorine atoms, and entrainment, J. Geophys. Res., 101(D1), 1907-1917.

Singh, H. B., W. H. Brune, J. H. Crawford, and D. J. Jacob (2006), Overview of the summer 2004 Intercontinental Chemical Transport Experiment-North America (INTEX-A), J. Geophys. Res., 111, D24S01, doi:10.1029/2006JD007905.

Solberg, S., C. Dye, N. Schmidbauer, A. Herzog, and G. Gehrig (1996), Carbonyls and nonmethane hydrocarbons at rural European sites from the Mediterranean to the Arctic, J. Atmos. Chem., 25(1), 33-66.

Spivakovsky, C. M., et al. (2000), Three dimensional climatological distribution of tropospheric OH: Update and evaluation, J. Geophys. Res., 105(D7), $8931-8980$.

Staudt, A. C., D. J. Jacob, J. A. Logan, D. Bachiochi, T. N. Krishnamurti, and N. Poisson (2002), Global chemical model analysis of biomass burn- ing and lightning influences over the South Pacific in austral spring, J. Geophys. Res., 107(D14), 4200, doi:10.1029/2000JD000296.

Staudt, A. C., D. J. Jacob, F. Ravetta, J. A. Logan, D. Bachiochi, T. N. Krishnamurti, S. Sandholm, B. Ridley, H. B. Singh, and B. Talbot (2003), Sources and chemistry of nitrogen oxides over the tropical Pacific, J. Geophys. Res., 108(D2), 8239, doi:10.1029/2002JD002139.

Stein, O., and J. Rudolph (2007), Modeling and interpretation of stable carbon isotope ratios of ethane in global chemical transport models, J. Geophys. Res., 112, D14308, doi:10.1029/2006JD008062.

Strapoć, D., M. Mastalerz, C. Eble, and A. Schimmelmann (2007), Characterization of the origin of coalbed gases in southeastern Illinois Basin by compound-specific carbon and hydrogen stable isotope ratios, Org. Geochem., 38(2), 267-287.

Streets, D. G., et al. (2003), An inventory of gaseous and primary aerosol emissions in Asia in the year 2000, J. Geophys. Res., 108(D21), 8809, doi:10.1029/2002JD003093.

Thompson, A. M., H. B. Singh, and H. Schlager (2000), Introduction to special section: Subsonic assessment ozone and nitrogen oxide experiment (SONEX) and pollution from aircraft emissions in the north Atlantic flight corridor (POLINAT 2), J. Geophys. Res., 105(D3), 3595-3603.

Thompson, A., J. Rudolph, F. Rohrer, and O. Stein (2003), Concentration and stable carbon isotopic composition of ethane and benzene using a global three-dimensional isotope inclusive chemical tracer model, J. Geophys. Res., 108(D13), 4373, doi:10.1029/2002JD002883.

Turquety, S., et al. (2007), Inventory of boreal fire emissions for North America in 2004: The importance of peat burning and pyro-convective injection, J. Geophys. Res., 112, D12S03, doi:10.1029/2006JD007281.

U.K. Photochemical Oxidant Review Group (PORG) (1997), Fourth Report of the Photochemical Oxidants Review Group, Dept. of the Environment, London, U.K.

Wang, Y., D. J. Jacob, and J. A. Logan (1998), Global simulation of tropospheric $\mathrm{O}_{3}-\mathrm{NOx}$-hydrocarbon chemistry. 1: Model formulation, J. Geophys. Res., 103(D9), 10,713-10,725.

Wang, J., J. Logan, M. McElroy, B. Duncan, I. Megretskaia, and R. Yantosca (2004), A 3-d model analysis of the slowdown and interannual variability in the methane growth rate from 1988 to 1997, Global Biogeochem. Cycles, 18, GB3011, doi:10.1029/2003GB002180.

Wang, J. S., M. B. McElroy, J. A. Logan, P. I. Palmer, W. L. Chameides, Y. Wang, and I. A. Megretskaia (2008), Quantitative assessment of uncertainties affecting estimates of global mean $\mathrm{OH}$ derived from methyl chloroform observations, J. Geophys. Res., 113, D12302, doi:10.1029/ 2007JD008496.

Xiao, Y. P., et al. (2004), Constraints on Asian and European sources of methane from $\mathrm{CH}_{4}-\mathrm{C}_{2} \mathrm{H}_{6}-\mathrm{CO}$ correlations in Asian outflow, J. Geophys. Res., 109, D15S16, doi:10.1029/2003JD004475.

Xiao, Y. P., D. J. Jacob, and S. Turquety (2007), Atmospheric acetylene and its relationship with $\mathrm{CO}$ as an indicator of air mass age, J. Geophys. Res., 112, D12305, doi:10.1029/2006JD008268.

Yevich, R., and J. A. Logan (2003), An assessment of biofuel use and burning of agricultural waste in the developing world, Global Biogeochem. Cycles, 17(4), 1095, doi:10.1029/2002GB001952.

Zhao, Y., et al. (2002), Spectroscopic measurements of tropospheric CO, $\mathrm{C}_{2} \mathrm{H}_{6}, \mathrm{C}_{2} \mathrm{H}_{2}$, and HCN in northern Japan, J. Geophys. Res., 107(D18), 4343, doi:10.1029/2001JD000748.

D. R. Blake, Department of Chemistry, University of California, 570 Rowland Hall, Irvine, Irvine, CA 92697-2025, USA.

R. C. Hudman, D. J. Jacob, J. A. Logan, and R. Yantosca, Department of Earth and Planetary Sciences and Division of Engineering and Applied Sciences, Harvard University, Pierce Hall, 29 Oxford St., Cambridge, MA 02138, USA.

Y. Xiao, Institute for the Study of Earth, Oceans and Space, University of New Hampshire, 8 College Road, Morse Hall 367, Durham, NH 03824, USA. (yxiao@gust.sr.unh.edu) 